Article

\title{
Fiscal, Investment and Export Multipliers and the COVID-19 Pandemic Slowdowns Uncertainty Factor in the First Half of 2020
}

\author{
Arkadiusz J. Derkacz \\ Economic Institute, University of Social Sciences, 00-842 Warsaw, Poland; aderkacz@san.edu.pl
}

Received: 8 October 2020; Accepted: 10 November 2020; Published: 16 November 2020

\begin{abstract}
The COVID-19 pandemic has caused a significant slowdown in the development of almost all economies in the world. In this context, the main goal of this research is to try to present changes in the value of fiscal, investment and export multipliers as a result of the COVID-19 pandemic. The research was conducted in selected European Union countries. They are France, Germany, Italy, Poland, Portugal and Spain. This research is based on the theory of effective demand. The values of feeds and leakages of total demand in the period from 2015 to 2020 were examined and calculated. On this basis, the individual multipliers of autonomous spending were analyzed and their changes in the first period of the COVID-19 pandemic were presented. The analyses led to a surprising conclusion: it found that the autonomous spending multipliers in some economies increased. This means that they have become 'security buffers' for the health of economies. This means that the increase in their value weakened the negative effects of changes in autonomous expenditure on gross domestic product.
\end{abstract}

Keywords: principle of efficient demand; fiscal multiplier; investment multiplier; export multiplier; COVID-19 pandemic slowdowns; uncertainty

\section{Introduction}

The beginning of 2020 for European societies has become a time of very serious epidemic threat from the COVID-19 virus. It did not take long for the implementation of sanitation to cause serious economic turbulence. From today's perspective, there is increasing talk of an economic crisis that is referred to as the COVID-19 pandemic slowdown. Thus, in the economic environment, more and more publications are emerging on the economic situation in the context of the COVID-19 pandemic.

The author attempts to describe the changes in the economic situation in France, Germany, Italy, Poland, Portugal and Spain. These countries were selected due to the fact that these are economies with different structures and characteristics. They are economies with very different structures, different economic dynamics and different structures of international trade. These economies are also at various stages of socio-economic transformation. There are different consumer habits and different economic strategies. The analysis of changes in such different economies as a result of the COVID-19 pandemic seems interesting. This will present the economic impact of the COVID-19 pandemic in different economies, using the multipliers of autonomous expenditure. The main objective of the research is to try to answer the question. Has the state of epidemic threat caused by COVID-19 contributed to changes in the fiscal, investment and export multipliers? This paper is an attempt to analyze the changes in the economy in the short term of selected countries from the perspective of factors feeding the combined demand in the economy. These include public spending, private investment and exports. Sources of leaks of total demand were also analyzed. In this context, there is talk of a tendency towards private consumption (as well as a tendency to private savings) and import levels of all components of domestic absorption. However, the analysis of changes in the economic situation is carried out only 
from the perspective of the multipliers of autonomous expenditure itself. The main research problem therefore focuses on possible changes in the value of multipliers and not on changes in gross domestic product, gross value added, level of remuneration or employment.

In order to achieve the main objective, the author examined the economic situation of selected European Union countries based on Eurostat statistics. The time perspective has been adopted from 2015. All data used were analyzed on a quarterly basis. This allowed the analysis of the economic effects during the first pandemic period of the COVID-19 virus; this is the first half of 2020. Soon, it is also worth examining the situation in subsequent periods of slowdown. Such studies of changes in fiscal, investment and export multipliers required some change in the methodology for calculating import-absorbency levels. Basic classes of goods in the national accounts system were used as the basis for the distribution of total imports. This made it possible to calculate import-intensive levels in the short term based on available statistics.

In the first part of the article, the author presents the economic basis for fiscal, investment and export multipliers research. It also describes how to calculate short-term import-intensive levels. Selected analyses and researches of the impact of the COVID-19 pandemic on national economies, available in the latest economic literature, are also presented. The second part shows the data collected and the relevant calculations are made to calculate the autonomous expenditure multipliers for the selected countries. They were calculated between the first quarter of 2015 and the first half of 2020 . It seems that the period of 5 years is enough of a background to show the changes that occurred in the first stage of the COVID-19 pandemic. At the end of this section, fiscal, investment and export multipliers for France, Germany, Italy, Poland, Portugal and Spain are presented. In the last part of the article, the author presents the most important conclusions. To this end, the changes in the multipliers of autonomous expenditure against the background of changes in GDP values are shown. Correlations between changes in fiscal, investment and export multipliers and changes in GDP are also presented. The relevant proposals are described for each of the selected countries. It turned out that the state of emergency caused by the COVID-19 virus significantly changed the economies of the selected countries in the short term. This caused uncertainty in the first period of the pandemic. It should be clearly emphasized that this uncertainty concerned the private and public sectors, entrepreneurs and employees, the sector of financial and nonfinancial enterprises. In short, the economic downturn caused by the COVID-19 virus pandemic has created uncertainty for entire national economies. Therefore, the author attempted to examine changes in the economy from the perspective of the fiscal, investment and export multiplier.

\section{Method}

The author used the same research method that is used in similar publications on the study of autonomous expenditure measures (Easki et al. 2010c; Palley 2009). The main foundation of the research is the theory of effective demand. Thus, the author completely rejects the assumptions of the mainstream economy, which speaks of the automatic pursuit of a free market economy to a state of equilibrium in full use of production capacity (Akerlof 2007; Dequech 2007). One of the fundamentals of the theory of efficient demand is the assumption that the economy is experiencing an inseparable state of instability (Akerlof and Yellen 1987). It is mainly dependent on investment decision processes. Equally important is the question of underutilization of production resources in capitalist economies. In this context, changes in gross domestic product remain determined by the volume of autonomous expenditure. These include expenditure on private investment, public spending and exports. In turn, the ratio of GDP change to changes in individual autonomous expenditures are called multipliers of this expenditure. So, we are dealing with a multiplier of public spending, an investment multiplier and an export multiplier. Regarding the issue of combined demand, it can be said that autonomous expenditure is a supply factor. This means that the increase in autonomous expenditure increases the value of gross domestic product. On the other hand, we are dealing with the so-called 'red tape' and leaks of total demand (Laski et al. 2012). In this context, taxes, imports and private savings 
are emerging. This means that the growth of these volumes in the economy is slowing its growth. The importance of the autonomous expenditure multipliers is derived from the principle of aggregate demand. It is totally accepted in this article. The multipliers show how much GDP changes due to changes in autonomous expenditure. This meaning was described in the literature that was used in the paper. The goal was not to verify their significance. This paper examined how their values changed during a pandemic.

The economic literature of the last few months has published quite a lot of research that analyzes the issue of the economic slowdown caused by the COVID-19 pandemic. The impact of the pandemic on the implementation of the sustainable development goals was analyzed. In this context, a warning is being sent on the need to continue to emphasize the achievement of the SDGs so that the progress achieved so far is not jeopardized (Fleetwood 2020; Leal Filho et al. 2020; Abhijit Mukherjee et al. 2020a). Many economists are analyzing the effects of the COVID-19 pandemic across industries and countries. Potential global economic costs as well as declines in GDP across countries are calculated (Fernandes 2020). The short-term and long-term effects on entire national economies and the environment are also analyzed (Malliet et al. 2020). There have also been studies on the impact of social distancing policies on economic activity and stock market indices. The effects of the COVID-19 pandemic are analyzed both in individual national economies and in the global economy (Bagchi et al. 2020; Nath 2020; Ozili and Arun 2020; Reinhart and Reinhart 2020).

Research into uncertainty, which is one of the more important consequences of the COVID-19 pandemic, has also appeared in recent months. This uncertainty applies to almost every aspect of the socio-economic space (Baker et al. 2020). In this context, economists analyze political responses/actions to the COVID-19 pandemic and its impact on the behavior of people and entrepreneurs in the economy on an ongoing basis (Debata et al. 2020). In the context of uncertainty, there is also a sense of fear among people about the potential possibility of losing a job and lowering wages. Social distancing, self-isolation and travel restrictions have led to a reduction in the workforce in all sectors of the economy and resulted in the loss of many jobs (Costa Dias et al. 2020; Nicola et al. 2020).

The COVID-19 pandemic also had a very strong impact on the functioning of global supply chains, which disrupted the optimal use of production capacity (Baldwin and di Mauro 2020). There is also a statement that the COVID-19 pandemic has caused "supply chain contamination" which has contributed to global problems for many production centers (Baldwin and Freeman 2020). All of this causes the COVID-19 pandemic to lead to dramatic changes in the way businesses and consumers operate in many sectors of the economy (Chang et al. 2020; Donthu and Gustafsson 2020).

The economic literature of recent months also shows studies on the impact of the COVID-19 pandemic on aspects of trade and food security (Erokhin and Gao 2020) as well as on the humanitarian problem (Mishra and Rampal 2020). The systems of managing and monitoring health in cities using the Smart City Network are also analyzed (Allam and Jones 2020). Analyses of the stock markets (Ko et al. 2018) and the security of financial investments are also valuable (Singh 2020). Individual groups of economists study the impact of the COVID-19 pandemic on the agricultural sector (Anirban Mukherjee et al. 2020b; Phillipson et al. 2020), energy (Gillingham et al. 2020), mining (Jowitt 2020) or the real estate market (Allen-Coghlan and McQuinn 2020). Analysis and research are also emerging that identify external and internal opportunities for creating new ventures during the COVID-19 pandemic. This is, in a sense, a positive and hopeful picture of the corporate sector. Increasingly, entrepreneurial practices can be seen as a catalyst for new business creation and economic growth following the end of the COVID-19 pandemic (Maritz et al. 2020).

The above issues, raised by many economists around the world, are very important. They show a very holistic aspect of the impact of the COVID-19 pandemic on national economies. One conclusion can be drawn from a critical analysis of these publications. The COVID-19 pandemic significantly influenced changes - and most often decreases - in the levels of individual expenditures in the economy. Declines in consumption and disposable income, reduced capacity utilization and layoffs, changes in the structure of government spending and contamination of global supply chains. These are probably 
the most important variables that reacted strongly to the COVID-19 pandemic. There are probably even more of these variables. Only some of them are mentioned above. However, it seems that all effects ultimately concern changes/decreases in autonomous expenditure. In this article, however, the author emphasized a slightly different perspective. If the analyzed socio-economic phenomena, including autonomous spending, slowed down significantly, how did this directly affect GDP? So how did the GDP or the GVA react to the falls/changes in main expenditure that shape this value? Therefore, it can be said that this approach is something new. In a way, it holds together all the economic effects of the COVID-19 pandemic.

In this context, autonomous expenditure multipliers show to what extent GDP responds to changes in individual expenditure. It turns out that a change in GDP is not always equal to a change in the value of autonomous expenditure. These reasons are disclosed in the multipliers in the so-called leaks. Therefore, studying changes in the value of the fiscal, investment and export multiplier is of great importance for forecasting economic policy. The stable level of these multipliers in the long term stabilizes the economic policy environment. Uncertainty associated with the volatility of autonomous expenditure multipliers may be a source of economic risk (Andrade et al. 2018). The problem of uncertainty about the value of the fiscal, investment and export multiplier is important both for the enterprise sector (Ko et al. 2018) and for the public sector (Fischer 2011; Schultz 2002). This approach to the issue of uncertainty in the economy is one of the reasons for testing the volatility of the fiscal, investment and export multiplier during the COVID-19 virus pandemic.

In addition to the main substantive foundation, the author also adopted the basic assumptions of the Keynesian model. These are assumptions that (1) the economy is underutilized by manufacturing factors, (2) foreign trade is balanced without major constraints, (3) there are slight changes in the distribution of national income between wages and gross profit margins, and (4) accommodative money supply policies are implemented. In this context, it must be concluded that gross domestic product is the sum of private consumption $(C P)$, private investment $(I P)$, public expenditure $(G)$, exports $(X)$ less import value $(M)$ (Easki 2019, pp. 1-5). This can be represented in the equation:

$$
Y=C P+I P+G+X-M
$$

If the sum of net taxes $(T N)$ is the difference between all tax revenues and burdens on the business sector and households and all public sector transfers, we obtain the amount of disposable income of the private sector $(Y D=Y-T N)$. At the same time, the size of the $T N$ will be public sector disposable income. Thus, there is a dependency $Y=Y D+T N$ and $Y D=Y-T N$. Let us now enter the gross savings value of the private sector $(S P)$. It is the difference between private sector disposable income and private consumption. On this basis, there is a dependency $C P=Y-T N-S P$ and $Y=C P+T N+S P$ (Easki et al. 2010a, p. 807).

Next, the concept of the average private savings rate $s p=\frac{S P}{Y}$ and the average net tax rate $t n=\frac{T N}{Y}$ should be introduced (Easki 2019, pp. 36, 59). On this basis, an equation was obtained that determines the level of private consumption $C P=(1-t n-s p) Y$. Assuming that $c p=(1-t n-s p)$, which means the propensity for private consumption in the economy, we have a formula:

$$
C P=c p Y
$$

Let us highlight the concept of national absorption $(A)$. This is the sum of the value of private investment $(I P)$, public expenditure including public investment $(G)$ and private consumption $(C P)$. You can save this in the equation:

$$
A=I P+G+C P
$$

If the national absorption is increased by the value of the export, we see the value of the final production $(F G=A+X)$. In the traditional approach, decomposition of imports is carried out on this basis. Determined the rates of import of final production, exports and domestic absorption (Łaski et al. 2010a). 
For this purpose, the import was divided according to the equation $M=M_{A}+M_{X}$. There was therefore an import of domestic absorption $\left(M_{A}\right)$ and import used to produce exported goods $\left(M_{X}\right)$. On this basis, import absorption coefficients were determined. The import absorbance of the national absorption was determined by the equation $m_{A}=M_{A} / A$. The import intensity of domestic absorption was determined by the equation $m_{X}=M_{X} / X$. On this basis, the value of imports in the form of a formula was determined:

$$
M=m_{A} c p Y+m_{A} I P+m_{A} G+m_{X} X
$$

Based on Equation (1), (4) and the equation $C P=c p Y$, after the corresponding transformations, received:

$$
Y=\frac{\left(1-m_{A}\right) G+\left(1-m_{A}\right) I P+\left(1-m_{X}\right) X}{1-c p\left(1-m_{A}\right)}
$$

In the traditional approach to the issue of the issue of the multipliers of autonomous expenditure, imports are even more disaggregated. Import of goods was assigned to each component of the total demand. There was therefore the importance of private consumption $\left(m_{C P}=M_{C P} / C P\right)$, public expenditure $\left(m_{G}=M_{G} / G\right)$, private investment $\left(m_{I P}=M_{I P} / I P\right)$ and exports $\left(m_{X}=M_{X} / X\right)$. On this basis, Equation (4) was verified. We get a new equation that determines the value of total imports of goods into the economy, which is used by domestic absorption and exports.

$$
M=m_{C P} c p Y+m_{I P} I P+m_{G} G+m_{X} X
$$

Using Equation (1) and (4'), the Equation (5) was also verified. At this point, it takes the form of:

$$
Y=\frac{\left(1-m_{G}\right) G+\left(1-m_{I P}\right) I P+\left(1-m_{X}\right) X}{1-c p\left(1-m_{C P}\right)}
$$

This equation was the basis for studying the volatility of autonomous expenditure multipliers during the economic slowdowns caused by the COVID-19 pandemic. This equation showed how autonomous variables determine the value of GDP. On the one hand, there was a variable $G, I P, X$, which fed the total demand. On the other hand, there was a coefficient of inclination to private consumption $(c p)$ and individual import-absorbency indicators. These values revealed to us the so-called leaks of total demand. It can therefore be said that autonomous expenditure, with certain demand leaks, sets the value of GDP. This is where the essence of the multipliers of autonomous expenditure is revealed (Easki 2019, pp. 99-103). They define the GDP response to changes in individual autonomous expenditures.

Before further analysis, one must consider a question. Various publications describing the multipliers of fiscal, investment and export expenditure show some methodological difficulties. It concerns the calculation of the national accumulation import absorbance index (Easki et al. 2010b, p. 17). Very often these publications are based on the balance of interbranch flows (Rueda-Cantuche et al. 2017; Statistics Poland 2019). The author proposed a different approach to the calculation of import-absorbency indicators. It was based on the distribution of imports by basic commodity classes in the system of national accounts (SNA) in terms of broad economic categories (BEC). Imports of goods were divided into imports of intermediate goods $\left(M_{D Z}\right)$, capital goods $\left(M_{D Z}\right)$ and consumer goods $\left(M_{D Z}\right)$. Total imports of goods could be determined as follows:

$$
M=M_{D Z}+M_{D I}+M_{D K}
$$

Such a divided import can be attributed to the main factors supplying domestic accumulation $(I P, C P, G)$ and export (X) (see Figure 1). Imports of consumer goods can be entirely attributed to private consumption $(C P)$. The import of capital goods is entirely absorbed by gross capital formation (IP). However, gross capital formation not only absorbs imported capital goods. It also uses imported 
intermediate goods $\left(M_{D Z}\right)$. Imported semifinished products are absorbed in the economy by gross capital formation, public spending and exports. In this context, an appropriate breakdown of imports of intermediate goods by certain coefficients is introduced. Intermediate goods can be absorbed by private investment, export production and public expenditure, which should be understood as total public expenditure including public investment. For this reason, it was necessary to introduce certain coefficients that will divide the import of intermediate goods.

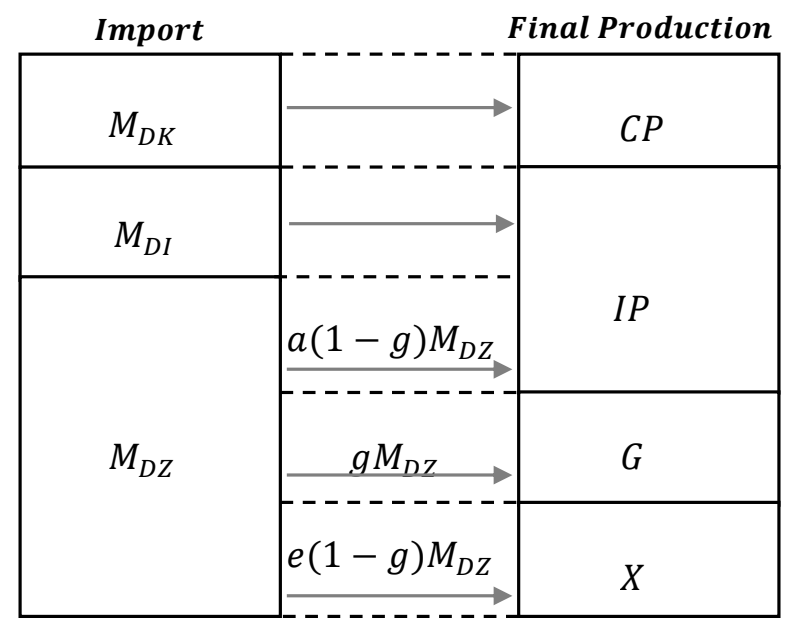

Figure 1. Import decomposition by broad economic categories (BEC), own work, sources: Eurostat.

Public expenditure $(G)$ should be understood as consumption in the public sector. In this way, part of the imports of intermediate goods is absorbed precisely for this expenditure. The author proposed that the amount of this absorption should be calculated based on the $g$ factor. It means the share of public expenditure in gross value added in a given period. It is worth noting here, as suggested by J. Toporowski, that such a division of imports of intermediate goods is useful in the short term. Long-term forecasting based on this import decomposition may produce erroneous results. This is because the national economy may change in the long term. Therefore, the author used a short period (quarter) in his calculations and the $g$ factor was calculated for each of the analyzed periods. Figure 2 shows this factor for selected European countries between 2015 and 2020 (quarterly layout). You can see that by the end of 2019 , the volatility rate is very low. It ranges from $0.61 \%$ for Poland to $1.93 \%$ for Portugal. On that basis, it can therefore be concluded that public expenditure absorbs imports of intermediate goods $g M_{D Z}$. The remainder of imports of intermediate goods $(1-g) M_{D Z}$ is absorbed by the final production of the business sector. For simplicity reasons, this value was called $p M_{D Z}$. The factor $p$ therefore means that part of the imports of intermediate goods which is absorbed by the undertakings $(p=1-g)$. Thus, imports of intermediate goods were distributed between the private and public sectors.

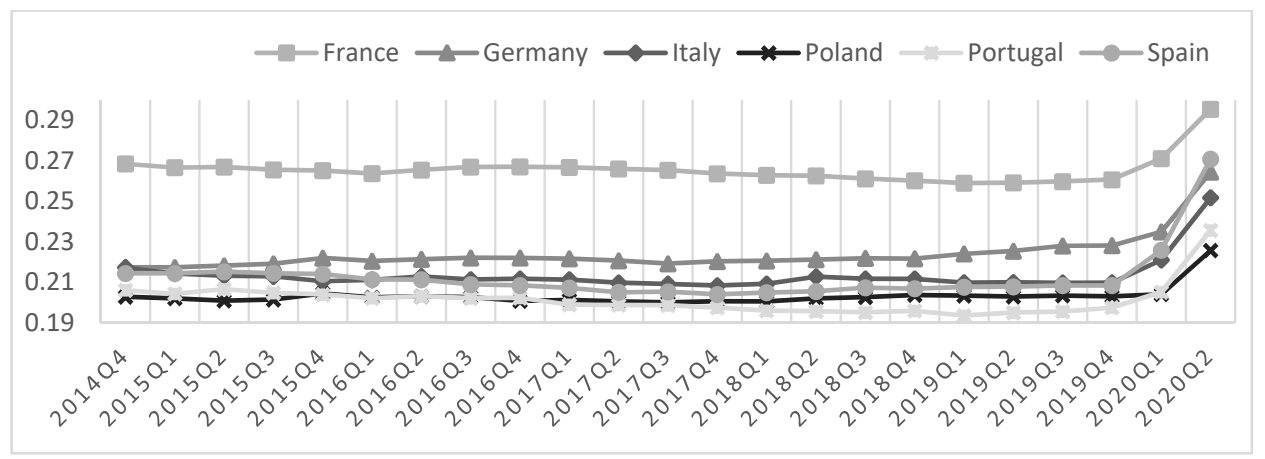

Figure 2. The coefficient of government spending in the gross value added, own work, source: Eurostat. 
There was still a division of some imports of intermediate goods $\left(p M_{D Z}\right)$ into national accumulation (more precisely into gross capital formation) and for export. The author proposed the $e$ factor. This coefficient means the share of exports in gross value added in a given period. The value of this coefficient should also be analyzed in the short term, similarly to the $g$ coefficient. Additionally, in this case, the author used quarterly data to calculate the $e$ coefficient (see Figure 3). In the period from 2015 to 2019 (quarterly) the coefficient of variation for selected countries ranged from 1.22\% for Germany to $4.87 \%$ for Poland. Using this coefficient, you can calculate the portion of imports of intermediate goods that will be used to produce goods for export. This value can be defined as $e(1-g) M_{D Z}$ or epM $M_{D Z}$. The remaining part of imported intermediate goods is absorbed for national absorption. Its value can be represented as $(1-e) p M_{D Z}$. Here you can enter the factor $a=1-e$, which will determine the share of this part of the import of intermediate goods absorbed for the purposes of gross capital formation $\left(a p M_{D Z}\right)$.

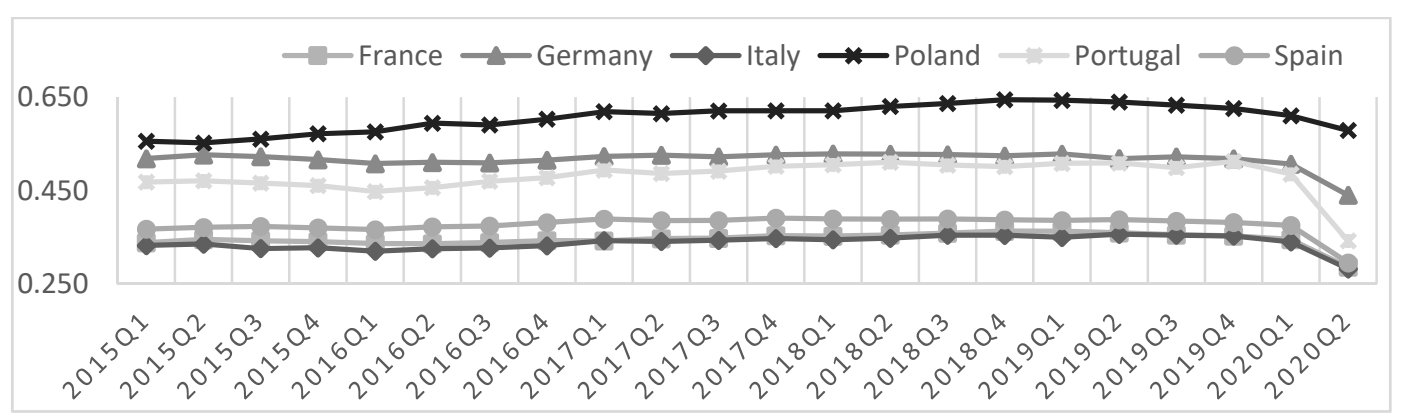

Figure 3. The coefficient of exports in output, own work, source: Eurostat.

In this way, the decomposition of total imports could be written by the equation:

$$
M=M_{D K}+\left(M_{D I}+a p M_{D Z}\right)+g M_{D Z}+e p M_{X}
$$

It follows that the import intensity of domestic accumulation is $M=M_{D K}+\left(M_{D I}+a p M_{D Z}\right)+$ $g M_{D Z}$. The import intensity of final production was additionally increased by the value of $e p M_{X}$. On this basis, it was possible to determine import intensity coefficients for individual autonomous expenses.

$$
m_{C P}=\frac{M_{D K}}{C P} ; m_{G}=\frac{g M_{D Z}}{G} ; m_{I P}=\frac{M_{D I}+a p M_{D Z}}{I P} ; m_{X}=\frac{e p M_{D Z}}{X}
$$

Import components defined in this way remain an approximate estimate. It seems, however, that such a solution may be valuable for a short-term analysis of import intensity and fiscal, investment and export multipliers.

Based on Equation (7), the fiscal $\left(k_{1}\right)$, investment $\left(k_{2}\right)$ and export $\left(k_{3}\right)$ multipliers were separated.

$$
k_{1}=\frac{\left(1-m_{G}\right)}{1-c p\left(1-m_{C P}\right)} ; k_{2}=\frac{\left(1-m_{I P}\right)}{1-c p\left(1-m_{C P}\right)} ; k_{3}=\frac{\left(1-m_{X}\right)}{1-c p\left(1-m_{C P}\right)}
$$

On this basis, the following was obtained using the short form of Equation (7):

$$
Y=k_{1} G+k_{2} I P+k_{3} X
$$

The value $Y$ is therefore completely dependent on the value of autonomous expenses and the $k$ factors. 
In traditional terms, the fiscal, investment and export multipliers determine how much the value of GDP changes when individual autonomous expenditure changes. The aim of the author's research was to analyze changes in the multipliers values during the economic slowdowns caused by the COVID-19 virus pandemic. For this purpose, changes in the value of autonomous expenditure were examined. Values of individual multipliers were also analyzed in quarterly periods. Therefore, Equation (7) takes the following form (Easki et al. 2010a, p. 810):

$$
\Delta Y=\frac{\left(1-m_{G}\right) \Delta G+\left(1-m_{I P}\right) \Delta I P+\left(1-m_{X}\right) \Delta X}{1-c p\left(1-m_{C P}\right)}
$$

This equation was the foundation for this research. It intended to show the response of a change in GDP to changes in autonomous expenditure at a given fiscal, investment and export multipliers during the economic slowdowns caused by the COVID-19 virus pandemic.

\section{Results of Calculations of Autonomous Expenditure Multipliers}

In this chapter, the author will calculate the values of individual indicators that determine the fiscal, investment and export multipliers. For this purpose, data provided by Eurostat were used. In order to present potential changes in the multipliers during the COVID-19 pandemic, the period from 2015 was adopted for analysis. Quarterly data was used. All calculations were carried out for selected European Union countries. They are France, Germany, Italy, Poland, Portugal and Spain.

First, the private consumption propensity factor $(c p)$ was calculated. According to the formula, this ratio is the ratio of private consumption to the value of gross domestic product $(c p=C P / Y)$. The ratio was calculated based on final consumption expenditure of households and gross domestic product at market prices. Data for selected European countries are presented in Table 1.

Table 1. Factor propensity to private consumption, own work, source: Eurostat.

\begin{tabular}{ccccccccccccc}
\hline Country & $\mathbf{2 0 1 5}$ & $\mathbf{2 0 1 5}$ & $\mathbf{2 0 1 5}$ & $\mathbf{2 0 1 5}$ & $\mathbf{2 0 1 6}$ & $\mathbf{2 0 1 6}$ & $\mathbf{2 0 1 6}$ & $\mathbf{2 0 1 6}$ & $\mathbf{2 0 1 7}$ & $\mathbf{2 0 1 7}$ & $\mathbf{2 0 1 7}$ & $\mathbf{2 0 1 7}$ \\
& $\mathbf{Q 1}$ & $\mathbf{Q} 2$ & $\mathbf{Q 3}$ & $\mathbf{Q 4}$ & $\mathbf{Q 1}$ & $\mathbf{Q 2}$ & $\mathbf{Q 3}$ & $\mathbf{Q 4}$ & $\mathbf{Q 1}$ & $\mathbf{Q 2}$ & $\mathbf{Q 3}$ & $\mathbf{Q 4}$ \\
\hline France & 0.519 & 0.522 & 0.520 & 0.518 & 0.518 & 0.523 & 0.521 & 0.524 & 0.522 & 0.519 & 0.518 & 0.517 \\
Germany & 0.517 & 0.516 & 0.516 & 0.515 & 0.512 & 0.512 & 0.514 & 0.515 & 0.511 & 0.509 & 0.507 & 0.505 \\
Italy & 0.601 & 0.605 & 0.603 & 0.602 & 0.596 & 0.595 & 0.595 & 0.597 & 0.601 & 0.598 & 0.595 & 0.593 \\
Poland & 0.581 & 0.581 & 0.581 & 0.568 & 0.578 & 0.575 & 0.579 & 0.577 & 0.578 & 0.575 & 0.574 & 0.577 \\
Portugal & 0.631 & 0.638 & 0.638 & 0.634 & 0.634 & 0.635 & 0.632 & 0.636 & 0.630 & 0.624 & 0.624 & 0.624 \\
Spain & 0.574 & 0.575 & 0.575 & 0.572 & 0.570 & 0.571 & 0.571 & 0.573 & 0.575 & 0.574 & 0.573 & 0.572 \\
\hline & $\mathbf{2 0 1 8}$ & $\mathbf{2 0 1 8}$ & $\mathbf{2 0 1 8}$ & $\mathbf{2 0 1 8}$ & $\mathbf{2 0 1 9}$ & $\mathbf{2 0 1 9}$ & $\mathbf{2 0 1 9}$ & $\mathbf{2 0 1 9}$ & $\mathbf{2 0 2 0}$ & $\mathbf{2 0 2 0}$ & & \\
France & $\mathbf{Q 1}$ & $\mathbf{Q 2}$ & $\mathbf{Q 3}$ & $\mathbf{Q 4}$ & $\mathbf{Q 1}$ & $\mathbf{Q 2}$ & $\mathbf{Q 3}$ & $\mathbf{Q 4}$ & $\mathbf{Q 1}$ & $\mathbf{Q 2}$ & & \\
Germany & 0.519 & 0.518 & 0.518 & 0.516 & 0.515 & 0.516 & 0.517 & 0.519 & 0.514 & 0.513 & & \\
Italy & 0.597 & 0.597 & 0.508 & 0.508 & 0.508 & 0.510 & 0.509 & 0.507 & 0.503 & 0.493 & & \\
Poland & 0.574 & 0.574 & 0.500 & 0.600 & 0.596 & 0.597 & 0.596 & 0.595 & 0.587 & 0.592 & & \\
Portugal & 0.623 & 0.625 & 0.625 & 0.528 & 0.566 & 0.566 & 0.565 & 0.564 & 0.562 & 0.541 & & \\
Spain & 0.574 & 0.572 & 0.572 & 0.568 & 0.566 & 0.562 & 0.564 & 0.559 & 0.553 & 0.531 & & \\
\hline
\end{tabular}

It is also worth calculating the average tax rate $(t n)$. It is the ratio of the sum of net taxes to gross domestic product $\left(t n=\frac{T N}{Y}\right)$. In the calculation of this coefficient, value of taxes less subsidies on products and gross domestic product at market prices was used. The calculated values are shown in Table 2. 
Table 2. Average tax rate, own work, source: Eurostat.

\begin{tabular}{ccccccccccccc}
\hline Country & $\mathbf{2 0 1 5}$ & $\mathbf{2 0 1 5}$ & $\mathbf{2 0 1 5}$ & $\mathbf{2 0 1 5}$ & $\mathbf{2 0 1 6}$ & $\mathbf{2 0 1 6}$ & $\mathbf{2 0 1 6}$ & $\mathbf{2 0 1 6}$ & $\mathbf{2 0 1 7}$ & $\mathbf{2 0 1 7}$ & $\mathbf{2 0 1 7}$ & $\mathbf{2 0 1 7}$ \\
$\mathbf{Q 1}$ & $\mathbf{Q 2}$ & $\mathbf{Q 3}$ & $\mathbf{Q 4}$ & $\mathbf{Q 1}$ & $\mathbf{Q 2}$ & $\mathbf{Q 3}$ & $\mathbf{Q 4}$ & $\mathbf{Q 1}$ & $\mathbf{Q 2}$ & $\begin{array}{c}\text { Q3 } \\
\mathbf{Q 4}\end{array}$ \\
\hline France & 0.104 & 0.105 & 0.105 & 0.105 & 0.105 & 0.106 & 0.106 & 0.107 & 0.109 & 0.110 & 0.110 & 0.109 \\
Germany & 0.099 & 0.100 & 0.101 & 0.103 & 0.100 & 0.099 & 0.100 & 0.100 & 0.102 & 0.099 & 0.098 & 0.098 \\
Italy & 0.101 & 0.102 & 0.102 & 0.099 & 0.101 & 0.102 & 0.103 & 0.102 & 0.102 & 0.104 & 0.103 & 0.103 \\
Poland & 0.112 & 0.111 & 0.113 & 0.113 & 0.113 & 0.116 & 0.118 & 0.120 & 0.122 & 0.122 & 0.122 & 0.121 \\
Portugal & 0.128 & 0.131 & 0.130 & 0.127 & 0.132 & 0.134 & 0.130 & 0.129 & 0.133 & 0.135 & 0.134 & 0.134 \\
Spain & 0.090 & 0.093 & 0.092 & 0.092 & 0.091 & 0.093 & 0.092 & 0.095 & 0.094 & 0.093 & 0.094 & 0.093 \\
\hline & $\mathbf{2 0 1 8}$ & $\mathbf{2 0 1 8}$ & $\mathbf{2 0 1 8}$ & $\mathbf{2 0 1 8}$ & $\mathbf{2 0 1 9}$ & $\mathbf{2 0 1 9}$ & $\mathbf{2 0 1 9}$ & $\mathbf{2 0 1 9}$ & $\mathbf{2 0 2 0}$ & $\mathbf{2 0 2 0}$ & & \\
France & $\mathbf{Q 1}$ & $\mathbf{Q 2}$ & $\mathbf{Q 3}$ & $\mathbf{Q 4}$ & $\mathbf{Q 1}$ & $\mathbf{Q 2}$ & $\mathbf{Q 3}$ & $\mathbf{Q 4}$ & $\mathbf{Q 1}$ & $\mathbf{Q 2}$ & & \\
Germany & 0.100 & 0.111 & 0.111 & 0.111 & 0.110 & 0.110 & 0.111 & 0.111 & 0.108 & 0.108 & & \\
Italy & 0.103 & 0.103 & 0.103 & 0.103 & 0.104 & 0.104 & 0.104 & 0.104 & 0.099 & 0.096 & & \\
Poland & 0.123 & 0.122 & 0.124 & 0.126 & 0.124 & 0.123 & 0.120 & 0.117 & 0.114 & 0.110 & & \\
Portugal & 0.135 & 0.133 & 0.139 & 0.137 & 0.135 & 0.136 & 0.135 & 0.138 & 0.133 & 0.123 & & \\
Spain & 0.094 & 0.095 & 0.095 & 0.095 & 0.095 & 0.093 & 0.093 & 0.091 & 0.095 & 0.078 & & \\
\hline
\end{tabular}

The import intensity indexes were calculated. To this end, the method described earlier was used (see Equations (8) and (9)). First, the import consumption coefficient of private consumption $\left(m_{C P}\right)$ can be calculated. It was defined as the ratio of imports of consumer goods to private consumption $\left(m_{C P}=M_{D K} / C P\right)$. The value of consumption goods, motor spirit and passenger motor cars and final consumption expenditure of households was used to calculate this indicator. The calculated indicators for selected countries are presented in Figure 4. During the COVID-19 virus pandemic, the value of this indicator dropped significantly in all of the countries analyzed. This is the reason for significant decreases in the import of consumer goods during this period.

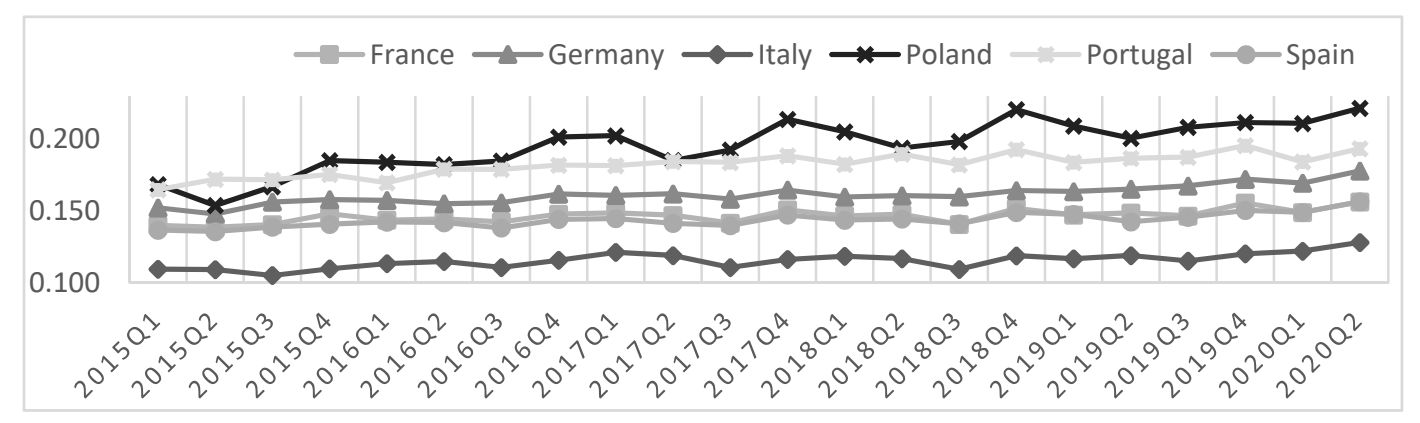

Figure 4. Import intensity coefficient of private consumption, own work, source: Eurostat.

Secondly, the import expenditure intensity ratio $\left(m_{G}\right)$ was calculated. It is defined as the ratio of imports of intermediate goods used by the government to the sum of public expenditure $\left(m_{G}=g_{g} M_{D Z} / G\right)$. The calculations are based on the value of import of intermediate goods and final consumption expenditure of general government. The $g$ factor has been discussed in the previous chapter (see Figure 2). The calculated $m_{G}$ indicators are shown in Figure 5. Additionally, the import intensity of public expenditure during the COVID-19 virus pandemic clearly decreased. The reason is very similar. Comparing imports of intermediate goods in the first quarter of 2020 and in the first half of 2019, there were very clear declines.

Next, the private investment intensity of import $\left(m_{I P}\right)$ was calculated. In the previous chapter it was described as $m_{I P}=M_{D I}+a p M_{D Z} / I P$. The calculations are based on the value of import of capital goods, import of intermediate goods and final consumption expenditure of general government. The $p$ and $a$ coefficient were discussed in the previous chapter. The results of the calculation are presented in Figure 6 . The results of the calculations are like previous import intensity indicators. It turns out that during the COVID-19 virus pandemic, the import intensity ratio also dropped significantly in all the 
countries analyzed. This time, the reason is a significant drop in imports of capital goods and imports of intermediate goods.

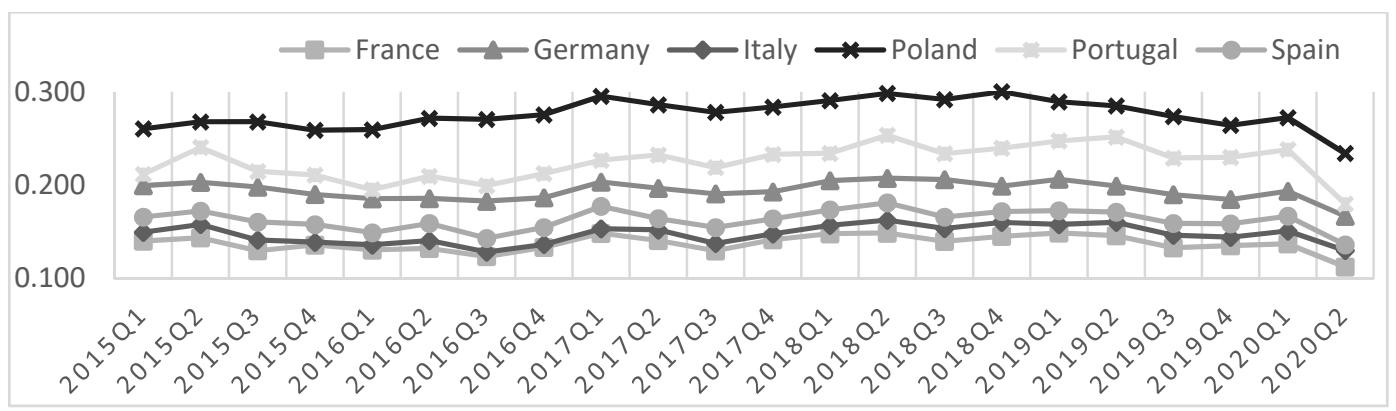

Figure 5. Import intensity coefficient of public expenditure, own work, source: Eurostat.

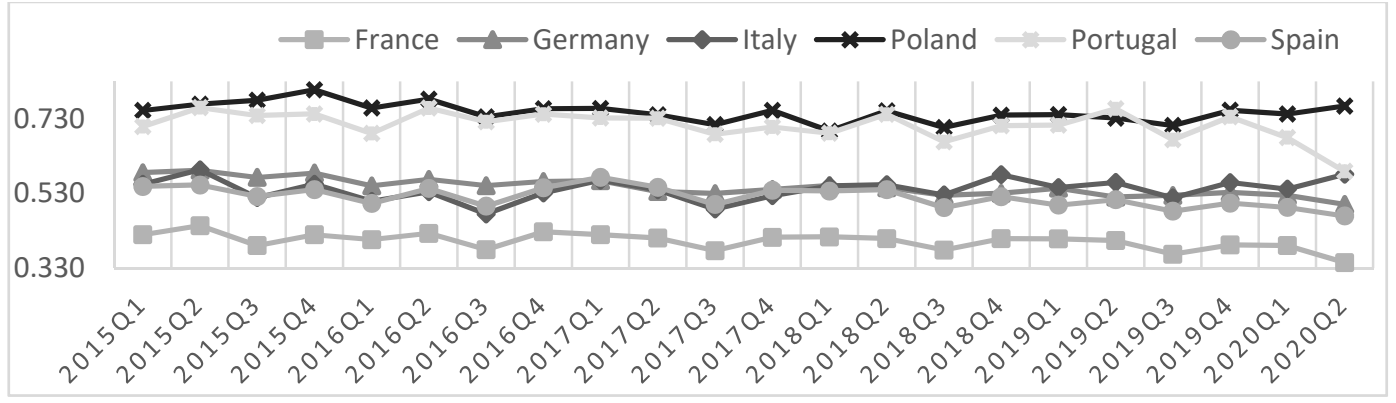

Figure 6. Import intensity coefficient of private investment, own work, source: Eurostat.

Finally, the import intensity of exports ratio $\left(m_{X}\right)$ was calculated. It was defined as the ratio of the part of the import of intermediate goods to the value of export $\left(m_{X}=e p M_{D Z} / X\right)$. The $e$ and $p$ indicators used here were discussed in an earlier chapter. The calculations are based on the value of import of intermediate goods and value of export of goods and services. The calculated indicators for selected countries are presented in Figure 7. The situation is also repeated in the results of this coefficient. In the first half of 2020 there was a strong decline in its value. The reasons for this should be sought in the decline in the value of imports of intermediate goods. It is worth adding, however, that the share of exports in global production (coefficient $e$ ) does not change significantly (see Figure 3). The coefficient of variation in the coefficient $e$ in the period from 1Q2015 to 2Q2020 was $4.43 \%$ for France, Germany $3.48 \%$, Italy $4.81 \%$, Poland $4.76 \%$, Portugal $7.43 \%$ and Spain $5.16 \%$.

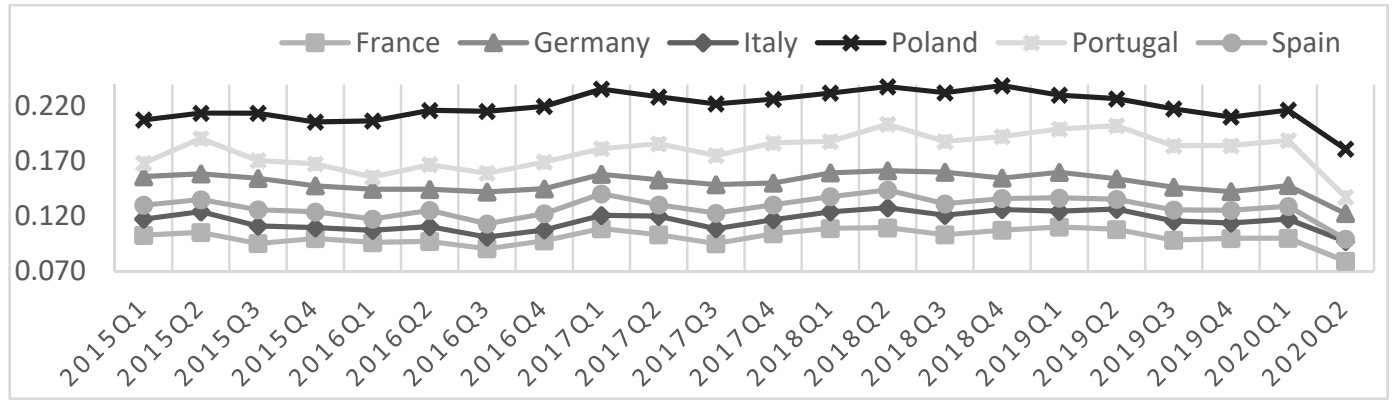

Figure 7. Import intensity coefficient of export, own work, source: Eurostat.

Based on the above results, the values of the fiscal $\left(k_{1}\right)$, investment $\left(k_{2}\right)$ and export $\left(k_{3}\right)$ multipliers can be calculated. For this purpose, the Equation (10) was used. A short period (1 quarter) was also adopted for the analysis. Table 3 presents the fiscal multiplier. Analyzing these data, in the 2Q2020 relative to 2Q2019 shows there was a marked increase in the fiscal multiplier in Portugal 
(6.32\%). This multiplier also increased in France (2.66\%), Germany (0.40\%), Italy (1.46\%) and Poland $(1.25 \%)$. The fiscal multiplier fell in Spain (-2.22\%). It is also worth noting that the fiscal multiplier in the analyzed countries, in the first stage of COVID-19 pandemic slowdowns, is not subject to significant changes.

Table 3. Fiscal multipliers, own work, source: Eurostat.

\begin{tabular}{|c|c|c|c|c|c|c|c|c|c|c|c|c|}
\hline Country & $\begin{array}{c}2015 \\
\text { Q1 }\end{array}$ & $\begin{array}{c}2015 \\
\text { Q2 }\end{array}$ & $\begin{array}{c}2015 \\
\text { Q3 }\end{array}$ & $\begin{array}{c}2015 \\
Q 4\end{array}$ & $\begin{array}{c}2016 \\
\text { Q1 }\end{array}$ & $\begin{array}{c}2016 \\
\text { Q2 }\end{array}$ & $\begin{array}{c}2016 \\
\text { Q3 }\end{array}$ & $\begin{array}{c}2016 \\
Q 4\end{array}$ & $\begin{array}{c}2017 \\
\text { Q1 }\end{array}$ & $\begin{array}{c}2017 \\
\text { Q2 }\end{array}$ & $\begin{array}{c}2017 \\
\text { Q3 }\end{array}$ & $\begin{array}{c}2017 \\
Q 4\end{array}$ \\
\hline France & 1.554 & 1.556 & 1.574 & 1.547 & 1.563 & 1.570 & 1.585 & 1.565 & 1.534 & 1.542 & 1.568 & 1.530 \\
\hline Germany & 1.425 & 1.422 & 1.420 & 1.431 & 1.432 & 1.435 & 1.444 & 1.431 & 1.395 & 1.400 & 1.412 & 1.397 \\
\hline Italy & 1.830 & 1.826 & 1.865 & 1.858 & 1.831 & 1.816 & 1.851 & 1.829 & 1.794 & 1.792 & 1.830 & 1.789 \\
\hline Poland & 1.432 & 1.441 & 1.418 & 1.380 & 1.402 & 1.375 & 1.382 & 1.343 & 1.308 & 1.343 & 1.345 & 1.311 \\
\hline Portugal & 1.668 & 1.609 & 1.664 & 1.654 & 1.699 & 1.652 & 1.664 & 1.641 & 1.596 & 1.564 & 1.593 & 1.553 \\
\hline \multirow[t]{3}{*}{ Spain } & 1.655 & 1.645 & 1.663 & 1.656 & 1.664 & 1.648 & 1.688 & 1.660 & 1.618 & 1.647 & 1.668 & 1.631 \\
\hline & 2018 & 2018 & 2018 & 2018 & 2019 & 2019 & 2019 & 2019 & 2020 & 2020 & & \\
\hline & Q1 & Q2 & Q3 & Q4 & Q1 & Q2 & Q3 & Q4 & Q1 & Q2 & & \\
\hline France & 1.530 & 1.525 & 1.550 & 1.521 & 1.518 & 1.523 & 1.551 & 1.539 & 1.533 & 1.564 & & \\
\hline Germany & 1.389 & 1.379 & 1.386 & 1.392 & 1.381 & 1.396 & 1.406 & 1.406 & 1.385 & 1.401 & & \\
\hline Italy & 1.779 & 1.767 & 1.816 & 1.782 & 1.780 & 1.773 & 1.807 & 1.796 & 1.752 & 1.799 & & \\
\hline Poland & 1.305 & 1.306 & 1.307 & 1.261 & 1.287 & 1.307 & 1.314 & 1.325 & 1.308 & 1.323 & & \\
\hline Portugal & 1.561 & 1.513 & 1.568 & 1.543 & 1.521 & 1.516 & 1.559 & 1.543 & 1.545 & 1.612 & & \\
\hline Spain & 1.627 & 1.603 & 1.639 & 1.602 & 1.600 & 1.601 & 1.623 & 1.603 & 1.575 & 1.566 & & \\
\hline
\end{tabular}

In the second place, the investment multiplier was calculated. Data for selected countries are presented in Table 4. Analyzing the 2Q2020 relative to 2Q2019, which is considered as the first stage of the COVID-19 pandemic, some changes can be seen. The investment multiplier value has fallen in Italy and Poland. In other economies, the relative changes in this period are positive. A very large increase was recorded in Portugal. It reached the level of $63.85 \%$. It is also worth noting that in the period from 2015 to 2020 there is quite a high volatility of this multiplier in the short term (quarter) in some economies. In Portugal the coefficient of variation is $12.2 \%$, in Poland $9.6 \%$ and in Italy $6.4 \%$.

Table 4. Investment multipliers, own work, source: Eurostat.

\begin{tabular}{ccccccccccccc}
\hline Country & $\mathbf{2 0 1 5}$ & $\mathbf{2 0 1 5}$ & $\mathbf{2 0 1 5}$ & $\mathbf{2 0 1 5}$ & $\mathbf{2 0 1 6}$ & $\mathbf{2 0 1 6}$ & $\mathbf{2 0 1 6}$ & $\mathbf{2 0 1 6}$ & $\mathbf{2 0 1 7}$ & $\mathbf{2 0 1 7}$ & $\mathbf{2 0 1 7}$ & $\mathbf{2 0 1 7}$ \\
& $\mathbf{Q 1}$ & $\mathbf{Q 2}$ & $\mathbf{Q 3}$ & $\mathbf{Q 4}$ & $\mathbf{Q 1}$ & $\mathbf{Q 2}$ & $\mathbf{Q 3}$ & $\mathbf{Q 4}$ & $\mathbf{Q 1}$ & $\mathbf{Q 2}$ & $\mathbf{Q 3}$ & $\mathbf{Q 4}$ \\
\hline France & 1.049 & 1.011 & 1.103 & 1.039 & 1.068 & 1.044 & 1.122 & 1.034 & 1.046 & 1.058 & 1.123 & 1.047 \\
Germany & 0.738 & 0.729 & 0.756 & 0.734 & 0.791 & 0.762 & 0.793 & 0.771 & 0.764 & 0.811 & 0.821 & 0.795 \\
Italy & 0.959 & 0.882 & 1.045 & 0.961 & 1.041 & 0.985 & 1.115 & 0.993 & 0.921 & 0.973 & 1.087 & 1.000 \\
Poland & 0.480 & 0.455 & 0.427 & 0.358 & 0.457 & 0.411 & 0.502 & 0.451 & 0.450 & 0.488 & 0.533 & 0.453 \\
Portugal & 0.615 & 0.509 & 0.554 & 0.539 & 0.653 & 0.504 & 0.578 & 0.537 & 0.553 & 0.547 & 0.636 & 0.592 \\
Spain & 0.896 & 0.889 & 0.947 & 0.904 & 0.972 & 0.895 & 0.993 & 0.894 & 0.840 & 0.894 & 0.986 & 0.901 \\
\hline & $\mathbf{2 0 1 8}$ & $\mathbf{2 0 1 8}$ & $\mathbf{2 0 1 8}$ & $\mathbf{2 0 1 8}$ & $\mathbf{2 0 1 9}$ & $\mathbf{2 0 1 9}$ & $\mathbf{2 0 1 9}$ & $\mathbf{2 0 1 9}$ & $\mathbf{2 0 2 0}$ & $\mathbf{2 0 2 0}$ & & \\
France & $\mathbf{Q 1}$ & $\mathbf{Q 2}$ & $\mathbf{Q 3}$ & $\mathbf{Q 4}$ & $\mathbf{Q 1}$ & $\mathbf{Q 2}$ & $\mathbf{Q 3}$ & $\mathbf{Q 4}$ & $\mathbf{Q 1}$ & $\mathbf{Q 2}$ & & \\
Germany & 0.784 & 1.058 & 1.120 & 1.052 & 1.055 & 1.063 & 1.132 & 1.082 & 1.083 & 1.154 & & \\
Italy & 0.950 & 0.791 & 0.830 & 0.817 & 0.794 & 0.836 & 0.825 & 0.806 & 0.816 & 0.840 & & \\
Poland & 0.557 & 0.463 & 0.542 & 0.470 & 0.469 & 0.491 & 0.521 & 0.445 & 0.463 & 0.408 & & \\
Portugal & 0.630 & 0.523 & 0.679 & 0.586 & 0.580 & 0.493 & 0.660 & 0.530 & 0.650 & 0.808 & & \\
Spain & 0.913 & 0.901 & 0.998 & 0.926 & 0.970 & 0.940 & 0.999 & 0.945 & 0.959 & 0.962 & & \\
\hline
\end{tabular}

The results of the calculation of the export multiplier are similar to the results of the fiscal multiplier. Detailed data are presented in Table 5. In 2Q2020, only in Spain a decrease in the value of the investment multiplier was recorded compared to 2Q2019. Other economies recorded relative increases in the value of the export multiplier over the same period. However, they were not high. Only in Portugal this value increased by $4.93 \%$. On this basis, it can be seen that in the first stage of 
COVID-19 pandemic slowdowns there were no significant changes in this regard. In the next chapter, we will examine in detail the economic situation of the analyzed European countries.

Table 5. Export multipliers, own work, source: Eurostat.

\begin{tabular}{ccccccccccccc}
\hline Country & $\mathbf{2 0 1 5}$ & $\mathbf{2 0 1 5}$ & $\mathbf{2 0 1 5}$ & $\mathbf{2 0 1 5}$ & $\mathbf{2 0 1 6}$ & $\mathbf{2 0 1 6}$ & $\mathbf{2 0 1 6}$ & $\mathbf{2 0 1 6}$ & $\mathbf{2 0 1 7}$ & $\mathbf{2 0 1 7}$ & $\mathbf{2 0 1 7}$ & $\mathbf{2 0 1 7}$ \\
& $\mathbf{Q 1}$ & $\mathbf{Q 2}$ & $\mathbf{Q 3}$ & $\mathbf{Q 4}$ & $\mathbf{Q 1}$ & $\mathbf{Q 2}$ & $\mathbf{Q 3}$ & $\mathbf{Q 4}$ & $\mathbf{Q 1}$ & $\mathbf{Q 2}$ & $\mathbf{Q 3}$ & $\mathbf{Q 4}$ \\
\hline France & 1.622 & 1.626 & 1.636 & 1.611 & 1.625 & 1.633 & 1.645 & 1.629 & 1.605 & 1.609 & 1.630 & 1.596 \\
Germany & 1.502 & 1.501 & 1.497 & 1.505 & 1.504 & 1.507 & 1.515 & 1.504 & 1.474 & 1.476 & 1.485 & 1.470 \\
Italy & 1.899 & 1.899 & 1.930 & 1.921 & 1.892 & 1.880 & 1.908 & 1.890 & 1.863 & 1.859 & 1.891 & 1.854 \\
Poland & 1.533 & 1.547 & 1.523 & 1.478 & 1.501 & 1.479 & 1.486 & 1.446 & 1.418 & 1.451 & 1.449 & 1.415 \\
Portugal & 1.759 & 1.714 & 1.757 & 1.745 & 1.783 & 1.740 & 1.748 & 1.730 & 1.689 & 1.658 & 1.682 & 1.646 \\
Spain & 1.725 & 1.719 & 1.731 & 1.723 & 1.726 & 1.713 & 1.747 & 1.723 & 1.691 & 1.713 & 1.731 & 1.697 \\
\hline & $\mathbf{2 0 1 8}$ & $\mathbf{2 0 1 8}$ & $\mathbf{2 0 1 8}$ & $\mathbf{2 0 1 8}$ & $\mathbf{2 0 1 9}$ & $\mathbf{2 0 1 9}$ & $\mathbf{2 0 1 9}$ & $\mathbf{2 0 1 9}$ & $\mathbf{2 0 2 0}$ & $\mathbf{2 0 2 0}$ & & \\
France & $\mathbf{Q 1}$ & $\mathbf{Q 2}$ & $\mathbf{Q 3}$ & $\mathbf{Q 4}$ & $\mathbf{Q 1}$ & $\mathbf{Q 2}$ & $\mathbf{Q 3}$ & $\mathbf{Q 4}$ & $\mathbf{Q 1}$ & $\mathbf{Q 2}$ & \\
Germany & 1.468 & 1.595 & 1.615 & 1.588 & 1.587 & 1.590 & 1.613 & 1.601 & 1.599 & 1.622 & & \\
Italy & 1.849 & 1.840 & 1.466 & 1.469 & 1.461 & 1.474 & 1.481 & 1.478 & 1.463 & 1.475 & & \\
Poland & 1.412 & 1.418 & 1.416 & 1.854 & 1.850 & 1.844 & 1.872 & 1.860 & 1.820 & 1.867 & & \\
Portugal & 1.655 & 1.614 & 1.661 & 1.638 & 1.393 & 1.413 & 1.414 & 1.422 & 1.408 & 1.414 & & \\
Spain & 1.697 & 1.676 & 1.706 & 1.671 & 1.669 & 1.670 & 1.687 & 1.666 & 1.646 & 1.633 & & \\
\hline
\end{tabular}

\section{Debatable Effects for the Economy}

The important significance of the fiscal, investment and export multipliers is that it shows the response of a change in GDP to changes in individual autonomous expenditure. Thus, they can be a source of information about the uncertain and unstable situation in the national economy. Modern economies are open organisms in which the global supply network is almost natural. The greater the import intensity of the economy, the more severe the problem becomes. It is therefore critical to use the right measures of import intensity in predicting the results of an active fiscal policy and estimating the multipliers linked to government spending (Łaski 2019, p. 101) as well as spending on private investment and export activities. The purpose of this paper was to analyze changes in multiplier values during the economic slowdowns caused by the COVID-19 virus pandemic. As a conclusion, it seems that the best solution will be to present changes in the value of the fiscal, investment and export multipliers in selected countries. The author presents these changes in the form of two graphs. The analysis adopted the period from the 1Q2015 to the 2Q2020. The first graph shows the relative changes in the values of the individual multipliers $\left(k_{1}, k_{2}, k_{3}\right)$ in relation to the corresponding quarter of the previous year $\Delta k=\left(k_{t+1}-k_{t}\right) / k_{t}$. In the same graph, on the auxiliary axis, the relative changes in the GDP value are also shown as $\left.\Delta Y=\left(Y_{t+1}-Y_{t}\right) / Y_{t}\right)$. The second graph shows the correlation between the relative changes of each of the multipliers and the relative changes of GDP. Here, points have been marked showing values during the economic slowdowns caused by the COVID-19 virus pandemic (1Q2020 and 2Q2020).

The significance of the fiscal, investment and export multipliers for the economy results directly from Equation (12). It shows that the change in the value of GDP is driven by an increase in autonomous expenditure (public expenditure, private investment and export). On the other hand, there is a leakage of demand in the form of propensity to consume and the level of import intensity. This means that the fiscal, investment and export multipliers (see Equation (10)) determine the value of total demand leaks that weaken the final value of autonomous expenditure and their impact on GDP change. Thus, they increase the level of uncertainty in the economy. Based on Equation (11) it can be said that the increase of the multiplier $k$ causes the acceleration of the GDP growth. However, the increase in this multiplier depends on the level of import intensity and the propensity for private consumption. The relationship is as follows: an increase in the level of import intensity reduces the value of the multiplier. On the other hand, the increase in the propensity to consume has a positive effect on the value of the multiplier. Of course, when talking about import intensity, an appropriate indicator should 
be selected due to the analyzed variable of autonomous expenditure. In this context, changes in the fiscal, investment and export multipliers during the economic slowdowns caused by the COVID-19 virus are analyzed.

\subsection{Changes in the French Economy}

The first pair of charts shows the changes in the autonomous expenditure multipliers for France. In 2 Q2020 a strong reaction of the investment multiplier can be observed. The value increased by $9 \%$ compared to 2Q2019. The values of other multipliers also increased. In the same period, the fiscal multiplier increased by $3 \%$ and the export multiplier by $2 \%$. There was also a marked decline in GDP during this period (see Figure 8). An interesting situation can be noticed when analyzing the correlation of changes in the value of individual multipliers to the value of GDP (see Figure 9). It can be seen that the points representing the analyzed relationships significantly differ from the values before the COVID-19 pandemic period. This may be a premise for a certain conclusion. During the COVID-19 pandemic, the French economy experienced a significant change in the relationship between GDP changes, autonomous expenditure and the importance of autonomous expenditure multipliers. Such a situation may increase uncertainty in the economy. At the same time, it may be a source of increased risk in terms of the effective implementation of fiscal, investment and trade policy in France.

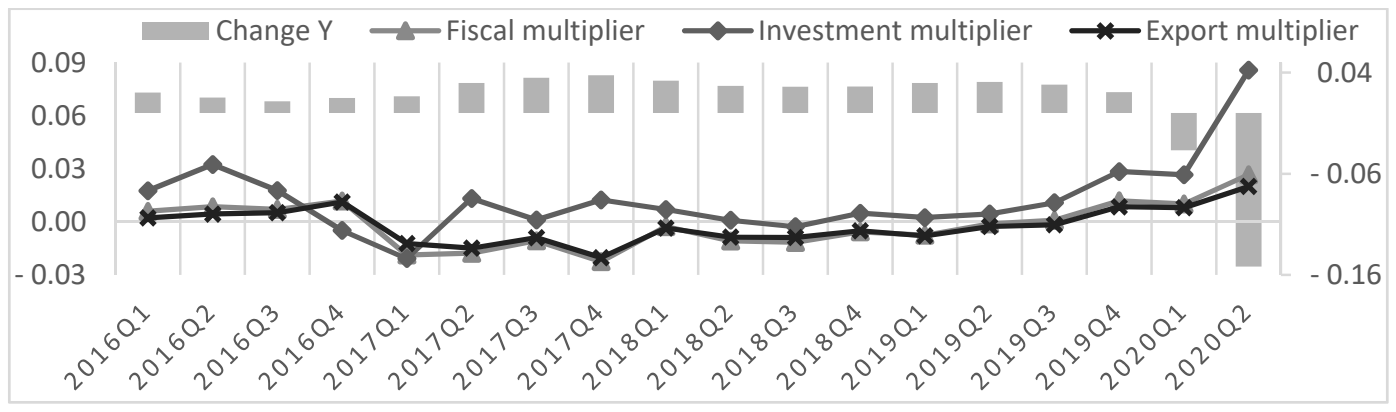

Figure 8. Changes in autonomous expenditure multipliers and GDP-France, own work, source: Eurostat.

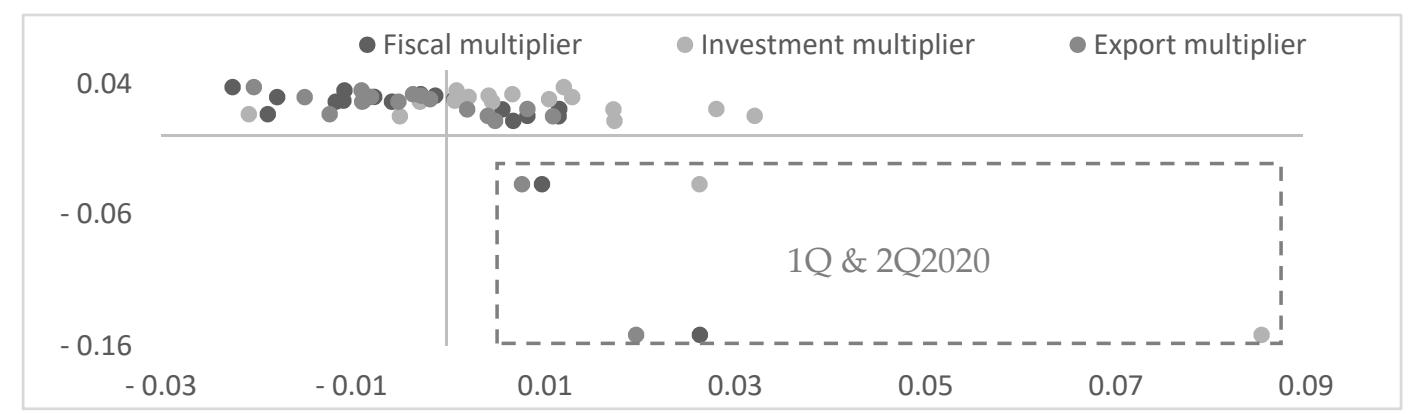

Figure 9. Correlation of changes in autonomous expenditure multipliers to GDP-France, own work, source: Eurostat.

\subsection{Changes in the German Economy}

Let us now look at the situation of the German economy during the COVID-19 pandemic. The results are different than in France. The value of the investment multiplier in Q1 2020 increased compared to Q1 2019, and then fell in Q2 2020 compared to Q2 2019. It is also visible that the value of this multiplier is characterized by a relatively high variability in relation to the other multipliers. These, in turn, reacted very poorly to the COVID-19 pandemic (see Figure 10). This may mean that the German economy has not experienced a significant change in the leakage level of aggregate demand at that time. Analyzing the results of the correlation of the relative changes of the autonomous expenditure 
multipliers to the relative changes of the GDP in Germany, similar conclusions can be drawn as seen in the situation of France (see Figure 11). You can also see here that the period of 2Q2020 brought significant changes. The points determining the correlation of changes in the fiscal, investment and export multiplier to changes in the GDP value differ from the points before the COVID-19 pandemic. However, these changes only concern the vertical system (GDP value).

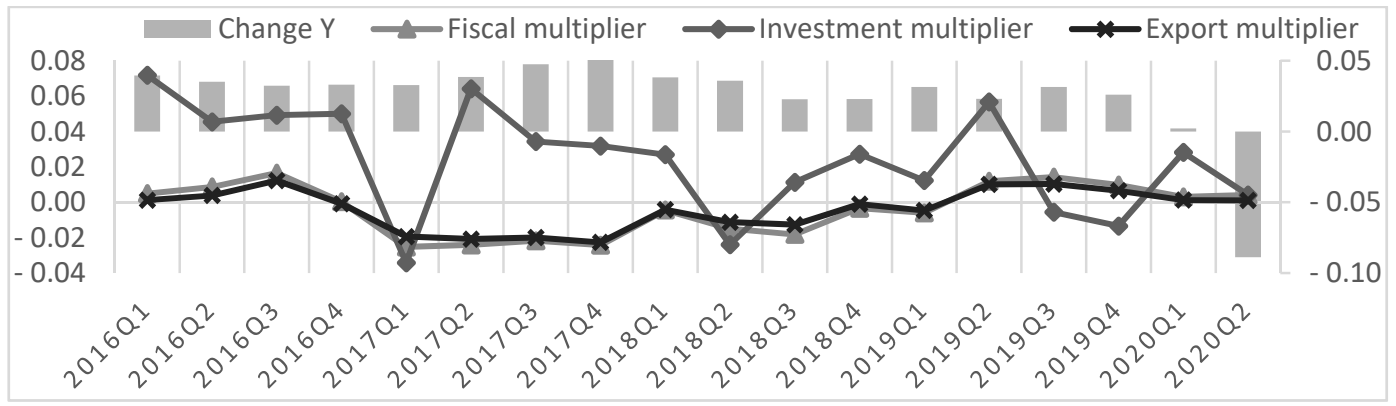

Figure 10. Changes in autonomous expenditure multipliers and GDP-Germany, own work, source: Eurostat.

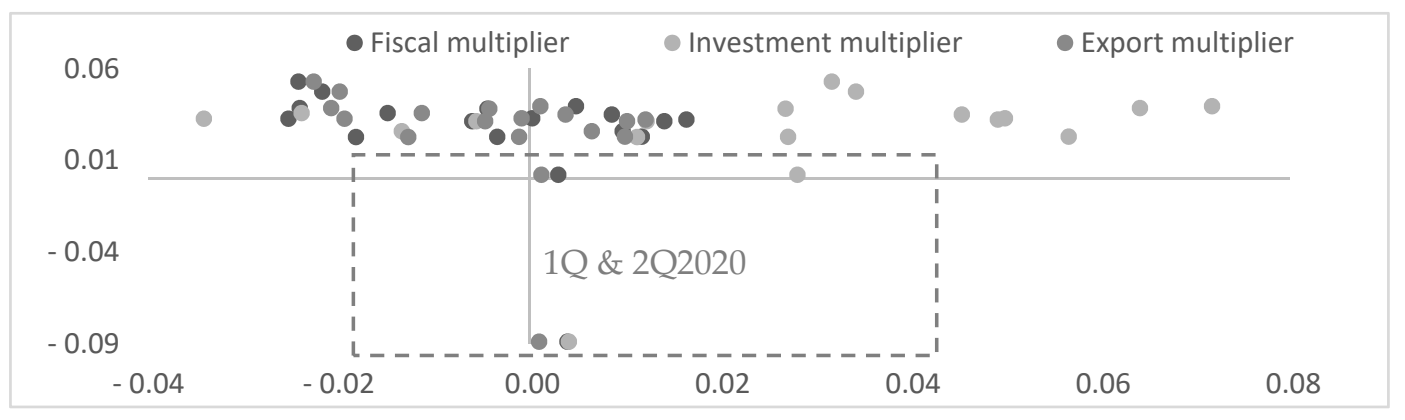

Figure 11. Correlation of changes in autonomous expenditure multipliers to GDP—Germany, own work, source: Eurostat.

\subsection{Changes in the Italian Economy}

We will now analyze the changes in the autonomous expenditure multipliers in Italy. Let us first look at the changes in the multipliers against the background of changes in the value of GDP (see Figure 12). We can see that in 2Q2020 the value of GDP also decreased significantly. In the last two quarters, quite strong decreases in the value of the investment multiplier were also recorded. In turn, the fiscal and export multipliers recorded slight increases in 2Q2020. This situation is poorly visible in Figure 12. This is due to the fact that the values of these two multipliers in the Italian economy have very similar values. This situation shows that total demand spills have weakened for these two multipliers. In turn, private investment is losing out on the increase in leakage of aggregate demand. This may mean that public spending and exports will have a stronger impact on the change in GDP in the coming quarters. When analyzing the relationship between the relative changes in the value of individual multipliers and the relative change in GDP, the situation is very similar to the previous one (see Figure 13). You can see that the relationship points in Q1 and Q2 of 2020 differ significantly from those before the economic slowdown caused by the COVID-19 pandemic. In this case, it can also be argued that in the Italian economy there has been a significant change in the relationship between changes in GDP, autonomous expenditure and the importance of the multipliers of autonomous expenditure. This situation can also be a source of uncertainty in the economy, especially in terms of private investment and exports. 


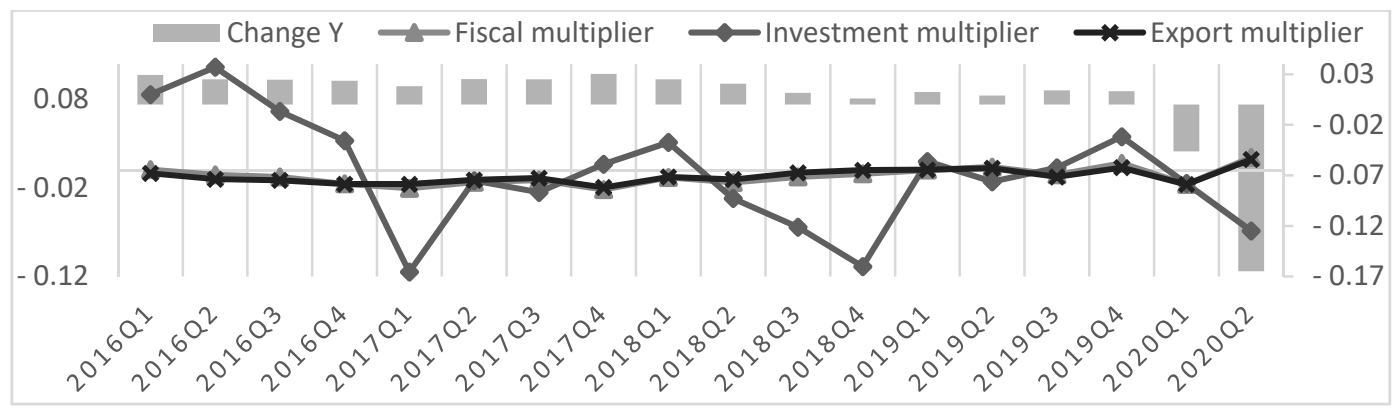

Figure 12. Changes in autonomous expenditure multipliers and GDP_Italy, own work, source: Eurostat.

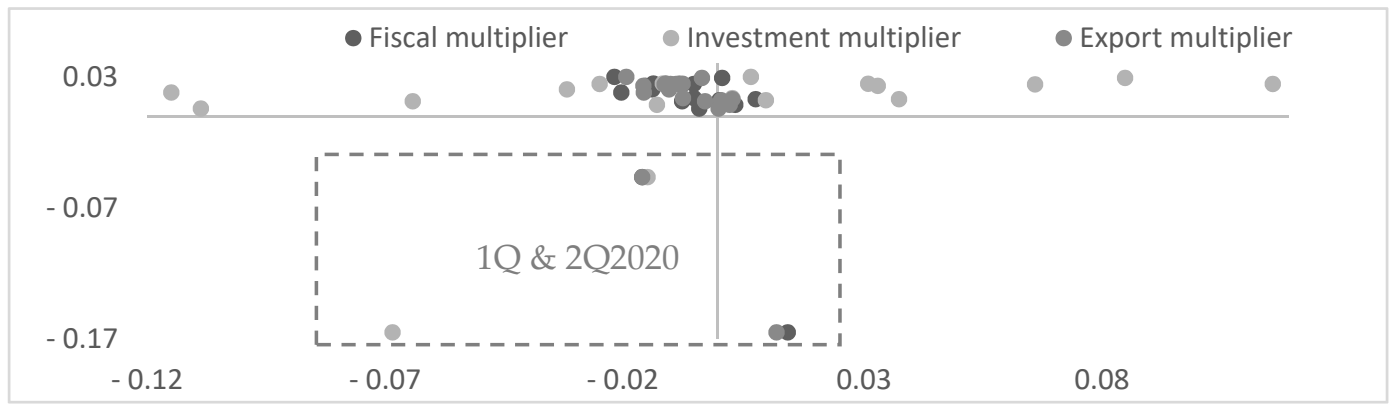

Figure 13. Correlation of changes in autonomous expenditure multipliers to GDP-Italy, own work, source: Eurostat.

\subsection{Changes in the Polish Economy}

Poland is another country that this paper will analyze. Let us look at the changes in the fiscal, investment and export multipliers against the background of changes in the level of GDP (see Figure 14). The first conclusion that comes to mind here concerns changes in GDP. It can be seen that the decline in GDP in Q1 2020 is much lower than in the other analyzed countries. A stronger negative change occurred in Q2 2020. The same quarter saw a slight increase in the fiscal multiplier. It can be assumed that this is the result of a decrease in the level of import intensity of intermediate and investment goods, which are used in domestic absorption. In addition, the reason may also be a decrease in the level of import intensity of consumer goods. In turn, the value of the export multiplier in Q2 2020 practically did not react compared to Q2 2019. However, the value of the investment multiplier dropped sharply. This may be the result of an increase in leakage of aggregate demand in business activities. On this basis, it can be seen that the economic situation of the Polish economy is quite characteristic. It can also be seen in the diagram of the relationship between the relative changes of individual multipliers and the relative changes of the GDP value (see Figure 15). The correlation of the fiscal, investment and export multiplier in 2Q2020 is boxed. The measurement points in 1Q2020, however, do not differ from the measurements in the other analyzed periods (this is marked with an arrow in the chart). Therefore, we can risk stating that the emergence of the COVID-19 virus threat changed the Polish economy in a different way. 


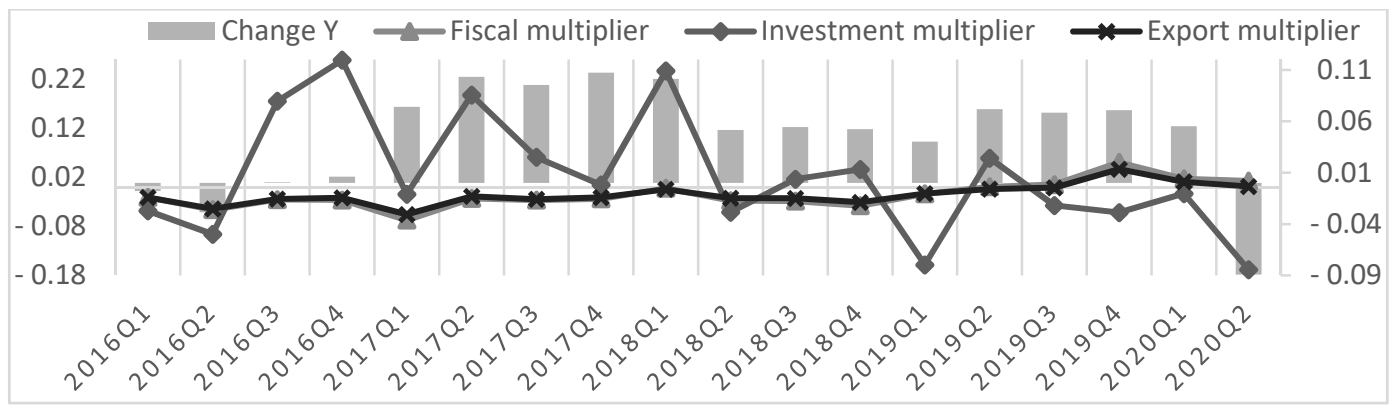

Figure 14. Changes in autonomous expenditure multipliers and GDP-Poland, own work, source: Eurostat.

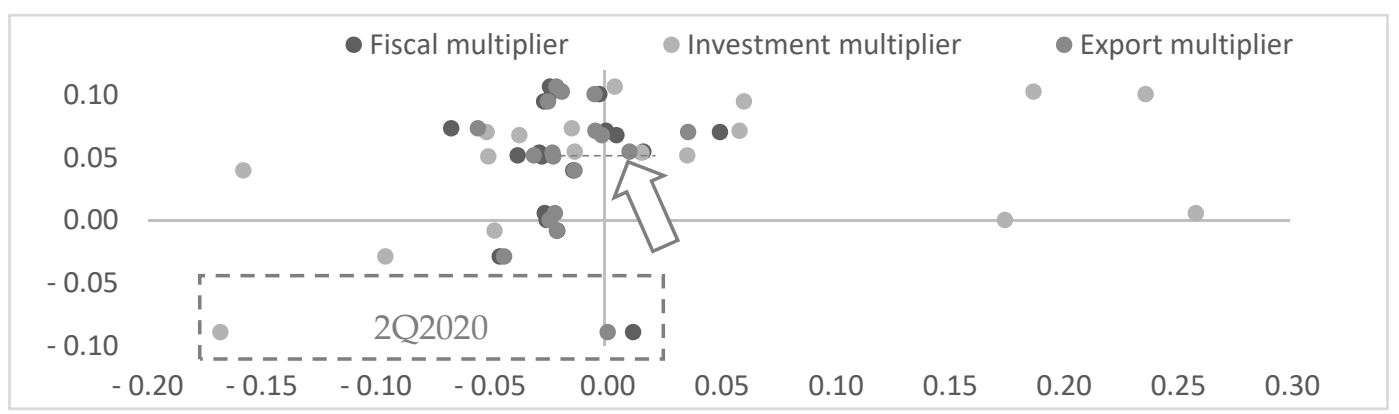

Figure 15. Correlation of changes in autonomous expenditure multipliers to GDP-Poland, own work, source: Eurostat.

\subsection{Changes in the Portuguese Economy}

Let us now look at the situation of the Portuguese economy. In the first stage of the COVID-19 pandemic, a significant decline in GDP was recorded in Portugal (see Figure 16). However, the situation of the multipliers is quite interesting. You can see that the investment multiplier in 2Q2020 increased significantly. The fiscal and export multipliers also increased during the same period. However, they are relatively small — this situation suggests certain conclusions. The Portuguese prone to private consumption must remain unchanged. It would be impossible for the $\mathrm{cp}$ factor in the denominator (see Equation (8)) to have such a different effect on the fiscal, investment and export multiplier. This is confirmed by the data presented in Table 1 . The reasons for these state of affairs should therefore be seen in the import intensity indicators. Now let us look at the correlation between the relative changes of individual multipliers and GDP (see Figure 17). Here the situation is similar to the French, Italian and German economies. The points denoting these relationships in Q1 and Q2 of 2020 also differ from those relating to the period before the COVID-19 pandemic. Therefore, one can risk a statement that in the Portuguese economy there has also been a reorientation of the relationship between changes in the value of GDP, autonomous expenditure and the importance of the multipliers of autonomous expenditure. The analysis of changes in the value of the autonomous expenditure multipliers allows us to state that this reorientation mainly concerns the import intensity structure. The level of private consumption and private saving in Portugal has remained unchanged or has changed very little. Such a situation may be a source of uncertainty in subsequent periods, as in the other analyzed economies. 


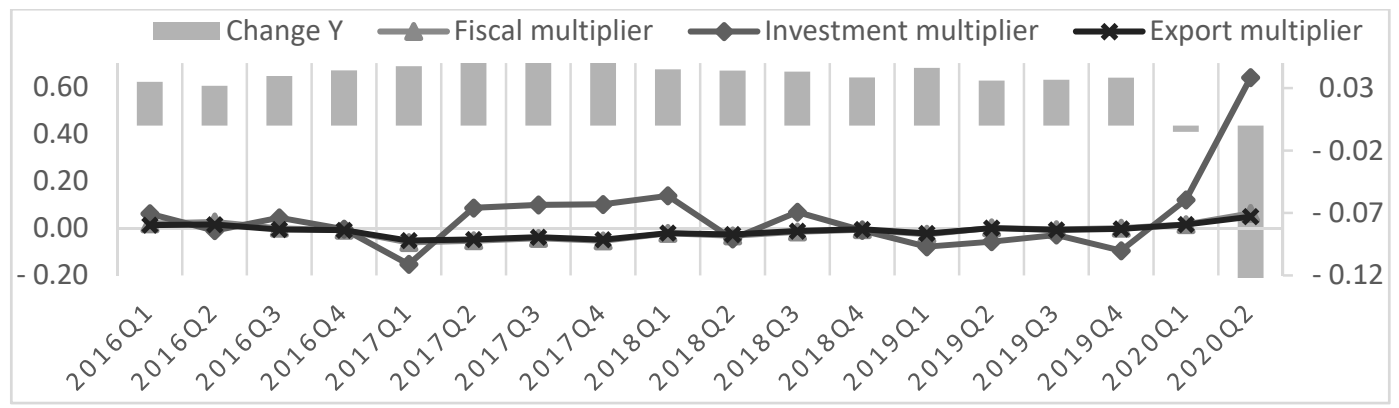

Figure 16. Changes in autonomous expenditure multipliers and GDP-Portugal, own work, source: Eurostat.

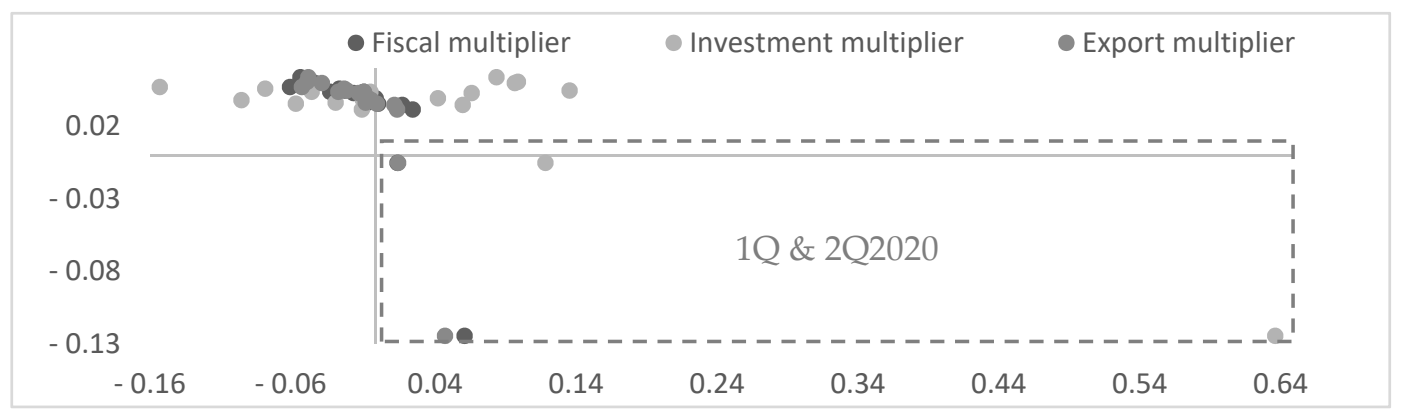

Figure 17. Correlation of changes in autonomous expenditure multipliers to GDP-Portugal, own work, source: Eurostat.

\subsection{Changes in the Spanish Economy}

Spain is the last country analyzed. In 2Q2020 Spain also saw a strong decline in GDP (see Figure 18). Additionally, there were clear declines in the fiscal and export multiplier. In contrast, the investment multiplier recorded an increase. This situation shows that the leakage of aggregate demand for government spending and exports has strengthened. On the other hand, the situation for private investment in the enterprise sector improved. It can be said that in Spain it is the gross capital formation expenditure that will most likely have the strongest (positive) influence on the change in GDP in this period. Government spending and exports are marked by an increase in leakage of aggregate demand, which adversely affects GDP growth. As a result, Spanish GDP is much less responsive to changes in government spending and exports. Let us analyze the correlation of changes in the fiscal, investment and export multipliers to the change in GDP in the Spanish economy (see Figure 19). At first glance, the situation is similar to other countries, except Poland. The points determining these relationships in 1Q2020 and 2Q2020 are significantly different from those before the COVID-19 pandemic. However, if we look closely at all the graphs that show these relationships, there is a subtle difference. We will note that the distance of the points from 2Q2020 to the remaining points from before the pandemic in Spain and Italy is significantly greater. Such an observation may lead to the following conclusion. In Spain and Italy, the first stage of the COVID-19 virus pandemic saw very large changes in the relationship between GDP changes, autonomous spending and the importance of autonomous spending multipliers. This can be seen, for example, in the changes in the levels of import intensity and the propensity to private consumption. Such a situation allows us to state that in the analyzed economies the level of economic uncertainty has increased. This can be a source of risk, particularly in terms of private investment and exports. 


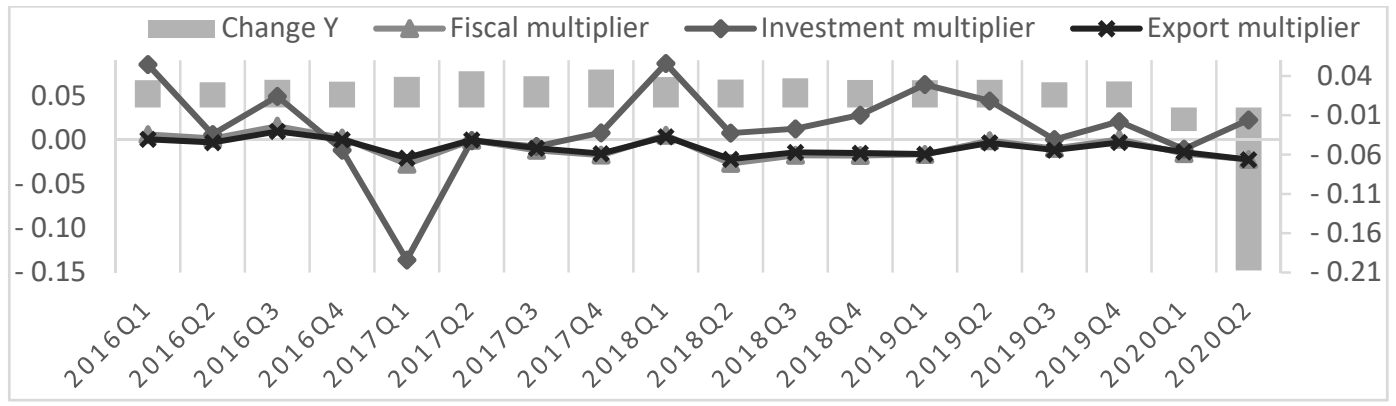

Figure 18. Changes in autonomous expenditure multipliers and GDP-Spain, own work, source: Eurostat.

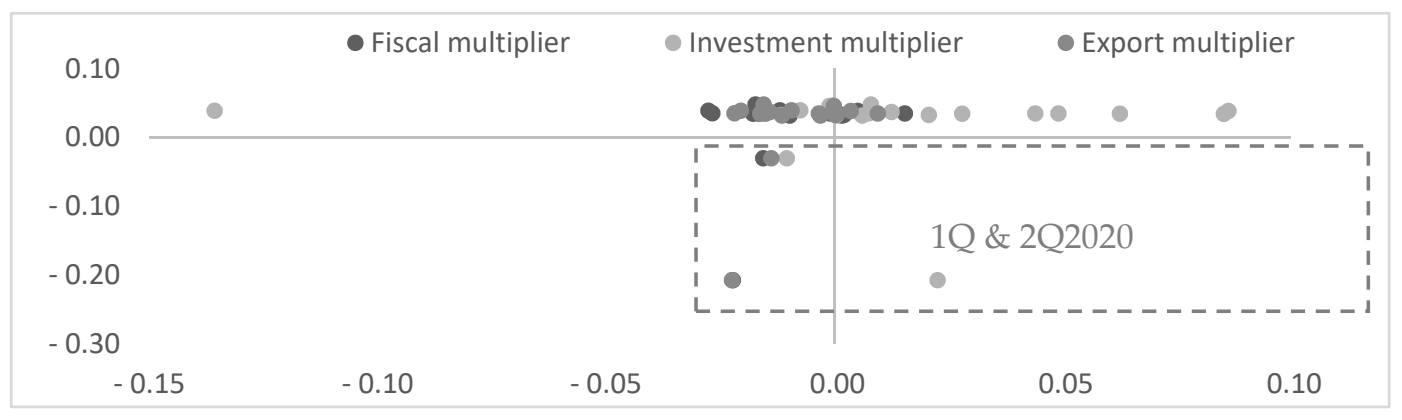

Figure 19. Correlation of changes in autonomous expenditure multipliers to GDP-Spain, own work, source: Eurostat.

\section{Discussion}

The most important conclusions from the research and analysis of the fiscal, investment and export multiplier for France, Germany, Italy, Poland, Portugal and Spain were presented above. However, one common conclusion can be drawn from them. The period of the COVID-19 virus pandemic brought about quite significant changes in the economic structure of the analyzed countries. It has been proven by testing all the variables that determine the values of the multipliers of autonomous expenses. In this context, it can be said that the economic slowdown caused by the COVID-19 virus pandemic has reinforced the leakage of aggregate demand, mainly in terms of private investment and export spending. This means that the crisis that affected all European countries-and almost all countries in the world-revealed a certain weakness in these areas of the economy. It has been shown that in 2Q2020, gross capital formation in most of the analyzed countries is marked by stronger leaks in aggregate demand. However, there are countries where the investment multiplier has improved significantly. As a result, the change in these expenditures is much weaker (or much better) at determining changes in the GDP of domestic economies. On the other hand, it has been proven that public spending is more resistant to shocks caused by the COVID-19 pandemic. In the analyzed countries, an increase, or relatively high relative stability, in the importance of state intervention was noted. This means that public spending is less prone to leakage of aggregate demand. On this basis, a final conclusion can be drawn. It can be said with certainty that the COVID-19 pandemic period brought about significant changes in the relationship between GDP changes, autonomous spending and the importance of autonomous spending multipliers. It has been shown that there have been changes in the propensity to private saving. There were also significant changes in import intensity indicators. Thus, this situation causes the stability of the economic structure to be disturbed-in some cases, very significantly. The presented analyses also showed that the COVID-19 pandemic influenced the study of the socio-economic phenomenon in very different ways. Therefore, one can risk a statement that the way in which the analyzed economies reacted to the outbreak of a pandemic depends on other ex ante factors. Regardless of this, it should be stated that economic instability may 
be a significant source of economic risk that emerged from the COVID-19 pandemic. All of this makes the analysis of the fiscal, investment and export multiplier valuable in the context of changes in the gross domestic product.

At the end of this article, an issue/conclusion for discussion can be proposed. It was said earlier that the fiscal, investment and export multipliers show how GDP reacts to changes in autonomous spending. At the same time, these multipliers reveal the impact of aggregate leakages on changes in GDP. Such dependencies are most often considered in the context of the dynamics of economic growth or the development economy of capitalist economies. However, the COVID-19 pandemic allows us to put the emphasis elsewhere. We can say that the multipliers of autonomous spending have shown us how changes (decreases) of GDP have reacted to changes (most often to decreases) of autonomous spending during the pandemic. In the classical approach, the multipliers revealed to us some limitations which inhibited the growth of the GDP value. These are, of course, leaks in total demand in the form of import intensity of autonomous expenditure and import intensity of private consumption. In the current global pandemic situation, these multipliers may be interpreted slightly differently. They may reveal to us not limitations, but safety buffers that slow down negative changes in GDP due to negative changes in autonomous spending. We will deal with such a situation under one condition. During the COVID-19 pandemic, these multipliers should increase in value. After all, the increase in the value of individual multipliers means that the leakage of aggregate demand will weaken. The conducted research has shown that we had to deal with such a situation not so rare. It happened that in 2Q2020 individual multipliers increased very significantly. The main determinant of the value of the fiscal, investment and export multipliers is the import intensity. Positive changes in the values of these multipliers will mean that the respective import intensity coefficients are weakening. This, in turn, means that the goods imported so far are generated by domestic demand. This situation, in turn, is positive for the domestic economy. Of course, the sequence of dependencies presented here has been greatly simplified. Nevertheless, we observe significant changes in international trade today. Based on this, some questions arise: Will the COVID-19 pandemic change trade balance structures in the long term? Will there be a permanent change in the value and importance of autonomous spending multipliers in European economies? Will global supply chains be redefined? Thus, the presented analyses can be an impulse for further research in this area. Ultimately, one more question can be asked: Will the changes we are seeing today, along with the socio-economic effects of the COVID-19 pandemic, contribute to the structural changes in European economies?

Funding: This research received no external funding.

Conflicts of Interest: The author declares no conflict of interest.

\section{References}

Akerlof, George A. 2007. The missing motivation in macroeconomics. American Economic Review 97: 5-36. [CrossRef]

Akerlof, George A., and Janet L. Yellen. 1987. Rational Models of Irrational Behavior. The American Economic Review 77: 137-42.

Allam, Zaheer, and David S. Jones. 2020. On the Coronavirus (COVID-19) Outbreak and the Smart City Network: Universal Data Sharing Standards Coupled with Artificial Intelligence (AI) to Benefit Urban Health Monitoring and Management. Healthcare 8: 46. [CrossRef] [PubMed]

Allen-Coghlan, Matthew, and Kieran McQuinn. 2020. Property prices and COVID-19 related administrative closures: What are the implications? International Journal of Housing Markets and Analysis 661: 1-22.

Andrade, Elisson, Fabio Mattos, and Roberto Arruda de Souza Lima. 2018. New Insights on Hedge Ratios in the Presence of Stochastic Transaction Costs. Risks 6: 118. [CrossRef]

Bagchi, Bhaskar, Susmita Chatterjee, Raktim Ghosh, and Dhrubaranjan Dandapat. 2020. Impact of COVID-19 on Global Economy. In Coronavirus Outbreak and the Great Lockdown. Berlin: Springer, pp. 15-26.

Baker, Scott R., Nicholas Bloom, Steven J. Davis, and Stephen J. Terry. 2020. COVID-Induced Economic Uncertainty. Working Paper No. 26983. Cambridge: National Bureau of Economic Research. [CrossRef] 
Baldwin, Richard, and Beatrice Weder di Mauro, eds. 2020. Economics in the Time of COVID-19. London: CEPR Press.

Baldwin, Richard, and Rebecca Freeman. 2020. Supply Chain Contagion Waves: Thinking ahead on Manufacturing 'Contagion and Reinfection' from the COVID Concussion. Available online: https://voxeu.org/article/covidconcussion-and-supply-chain-contagion-waves (accessed on 1 October 2020).

Chang, Chia-Lin, Michael McAleer, and Wing-Keung Wong. 2020. Risk and Financial Management of COVID-19 in Business, Economics and Finance. Journal of Risk and Financial Management 13: 102. [CrossRef]

Costa Dias, Monica, Robert Joyce, Fabien Postel-Vinay, and Xiaowei Xu. 2020. The challenges for labour market policy during the Covid-19 pandemic. Fiscal Studies 41: 371-82. [CrossRef] [PubMed]

Debata, Byomakesh, Pooja Patnaik, and Abhisek Mishra. 2020. COVID-19 pandemic! It's impact on people, economy, and environment. Journal of Public Affairs, e2372. [CrossRef]

Dequech, David. 2007. Neoclassical, mainstream, orthodox, and heterodox economics. Journal of Post Keynesian Economics 30: 279-302. [CrossRef]

Donthu, Naveen, and Anders Gustafsson. 2020. Effects of COVID-19 on business and research. Journal of Business Research 117: 284-89. [CrossRef]

Erokhin, Vasilii, and Tianming Gao. 2020. Impacts of COVID-19 on Trade and Economic Aspects of Food Security: Evidence from 45 Developing Countries. International Journal of Environmental Research and Public Health 17: 5775. [CrossRef] [PubMed]

Fernandes, Nuno. 2020. Economic Effects of Coronavirus Outbreak (COVID-19) on the World Economy; SSRN Scholarly Paper ID 3557504. Social Science Research Network. Available online: https://papers.ssrn.com/abstract= 3557504 (accessed on 1 October 2020).

Fischer, Peter. 2011. Selective Exposure, Decision Uncertainty, and Cognitive Economy: A New Theoretical Perspective on Confirmatory Information Search. Social and Personality Psychology Compass 5: 751-62. [CrossRef]

Fleetwood, Janet. 2020. Social justice, food loss, and the sustainable development goals in the era of COVID-19. Sustainability 12: 5027. [CrossRef]

Gillingham, Kenneth T., Christopher R. Knittel, Jing Li, Marten Ovaere, and Mar Reguant. 2020. The Short-run and Long-run Effects of Covid-19 on Energy and the Environment. Joule 4: 1337-41. [CrossRef]

Jowitt, Simon M. 2020. COVID-19 and the Global Mining Industry. SEG Discovery 122: 33-41. [CrossRef]

Ko, Chuan-Chuan, Tyrone T. Lin, Fu-Min Zeng, and Chien-Yu Liu. 2018. Optimum Technology Product Life Cycle Technology Innovation Investment-Using Compound Binomial Options. Risks 6: 98. [CrossRef]

Łaski, Kazimierz. 2019. Lectures in Macroeconomics: A Capitalist Economy without Unemployment. Oxford: Oxford University Press.

Łaski, Kazimierz, Jerzy Osiatyński, and Jolanta Zięba. 2010a. Czynniki wzrostu PKB w Polsce i w Czechach w 2009 r. Ekonomista 6: 805-30.

Łaski, Kazimierz, Jerzy Osiatyński, and Jolanta Zięba. 2010b. Mnożnik Wydatków Państwowych i Szacunki jego Wielkości dla POLSKI. Warsaw: Narodowy Bank Polski, Departament Edukacji i Wydawnictw.

Łaski, Kazimierz, Jerzy Osiatyński, and Jolanta Zięba. 2010c. The Government Expenditure Multiplier and its Estimates for Poland in 2006-2009. Working Paper of Vienna Institute for International Economic Studies 63: 1-14.

Laski, Kazimierz, Jerzy Osiatyński, and Jolanta Zięba. 2012. Fiscal Multipliers and Factors of Growth in Poland and the Czech Republic in 2009. National Bank of Poland Working Paper 117: 1-28. [CrossRef]

Leal Filho, Walter, Luciana Londero Brandli, Amanda Lange Salvia, Lez Rayman-Bacchus, and Johannes Platje. 2020. COVID-19 and the UN Sustainable Development Goals: Threat to Solidarity or an Opportunity? Sustainability 12: 5343. [CrossRef]

Malliet, Paul, Frédéric Reynès, Gissela Landa, Meriem Hamdi-Cherif, and Aurélien Saussay. 2020. Assessing Short-Term and Long-Term Economic and Environmental Effects of the COVID-19 Crisis in France. Environmental and Resource Economics 76: 867-83. [CrossRef] [PubMed]

Maritz, Alex, Aron Perenyi, Gerrit de Waal, and Christoph Buck. 2020. Entrepreneurship as the Unsung Hero during the Current COVID-19 Economic Crisis: Australian Perspectives. Sustainability 12: 4612. [CrossRef]

Mishra, Khushbu, and Jeevant Rampal. 2020. The COVID-19 pandemic and food insecurity: A viewpoint on India. World Development 135: 105068. [CrossRef]

Mukherjee, Abhijit, S. Suresh Babu, and Subimal Ghosh. 2020a. Thinking about water and air to attain Sustainable Development Goals during times of COVID-19 Pandemic. Journal of Earth System Science 129: 1-8. [CrossRef] 
Mukherjee, Anirban, Ujjwal Kumar, Kumari Shubha, and Shreya Anand. 2020b. Implications of COVID-19 on agriculture in eastern region. Food and Scientific Reports 1: 63-66.

Nath, Hiranya. 2020. Covid-19: Macroeconomic impacts and policy issues in India. Space and Culture India 8: 1-13. [CrossRef]

Nicola, Maria, Zaid Alsafi, Catrin Sohrabi, Ahmed Kerwan, Ahmed Al-Jabir, Christos Iosifidis, Maliha Agha, and Riaz Agha. 2020. The socio-economic implications of the coronavirus pandemic (COVID-19): A review. International Journal of Surgery (London, England) 78: 185-93. [CrossRef]

Ozili, Peterson K., and Thankom Arun. 2020. Spillover of COVID-19: Impact on the Global Economy; SSRN Scholarly Paper ID 3562570. Social Science Research Network. Available online: https://papers.ssrn.com/abstract= 3562570 (accessed on 1 October 2020).

Palley, Thomas I. 2009. Imports and the income-expenditure model: Implications for fiscal policy and recession fighting. Journal of Post Keynesian Economics 32: 311-22. [CrossRef]

Phillipson, Jeremy, Matthew Gorton, Roger Turner, Mark Shucksmith, Katie Aitken-McDermott, Francisco Areal, Paul Cowie, Carmen Hubbard, Sara Maioli, Ruth McAreavey, and et al. 2020. The COVID-19 Pandemic and Its Implications for Rural Economies. Sustainability 12: 3973. [CrossRef]

Reinhart, Carmen, and Vincent Reinhart. 2020. The pandemic depression: The global economy will never be the same. Foreign Affairs 99: 84.

Rueda-Cantuche, José M., Antonio F. Amores, Joerg Beutel, and Isabelle Remond-Tiedrez. 2017. Assessment of European Use tables at basic prices and valuation matrices in the absence of official data. Economic Systems Research 30: 252-70. [CrossRef]

Schultz, Christian. 2002. Policy biases with voters' uncertainty about the economy and the government. European Economic Review 46: 487-506. [CrossRef]

Singh, Amanjot. 2020. COVID-19 and safer investment bets. Finance Research Letters 36: 101729. [CrossRef] [PubMed]

Statistics Poland. 2019. Input-Output Table at Basic Prices in 2015 [Statistical information]. Warsaw: Statistics Poland.

Publisher's Note: MDPI stays neutral with regard to jurisdictional claims in published maps and institutional affiliations.

(C) 2020 by the author. Licensee MDPI, Basel, Switzerland. This article is an open access article distributed under the terms and conditions of the Creative Commons Attribution (CC BY) license (http://creativecommons.org/licenses/by/4.0/). 